\title{
The Impact of Materialism on Consumer Ethics: An Empirical Study on Adult Students in Hong Kong
}

\author{
Olivia, Lai Wah Lui \\ Hong Kong University \\ Hong Kong, China \\ E-mail: olivia.lui@hkuspace.hku.hk. \\ Canon Tong \\ International Graduate School of Business \\ University of South Australia \\ Adelaide SA, Australia \\ E-mail: canon.tong@unisa.edu.au \\ Anthony Wong \\ Newcastle Graduate School of Business \\ University of Newcastle \\ Callaghan NSW, Australia \\ E-mail: anthonywong628@yahoo.com
}

Received: January 4, 2012

Accepted: January 26, 2012 Published: April 1, 2012

doi:10.5296/jmr.v4i2.1233

URL: http://dx.doi.org/10.5296/jmr.v4i2.1233

\begin{abstract}
This research examined the relationship between materialism and the unethical behaviour of consumers and how demographic variables affect the relationship between materialism and consumer ethics. A research framework with five hypotheses was established to examine these relationships. The study adopted the consumer ethics scale and the measure of materialistic attitudes scale (MMA) used in prior studies. Based on convenience sampling, 303 participants completed an anonymous questionnaire. Multiple-indicators were used to
\end{abstract}




\section{Macrothink

measure the two variables of materialism and consumer ethics with respondents being asked to answer a number of questions for each variable. Cronbach's alpha value was used to test internal reliability. Data were analysed by using descriptive analysis, exploratory factor analysis, Pearson product moment correlation, independent samples t-test, and multiple regression analysis. Findings indicate that the relationship between materialism and consumer ethics is not significant and that demographic variables of age, income and education all have a moderating effect on the relationship with education being a very important factor in developing a healthy ethical attitude among young people which may prompt governments to allocate more resource to education and encourage educators to pay more attention to moral and civic education.

Keywords: Materialism, Consumer ethics, Ethical attitude, Code of ethics, Ethical decision-making behaviour 


\section{Introduction}

Considerable attention has been paid to ethical problems in businesses since the late 1970s, with intense interest from both academics and business practitioners (Vitell and Muncy, 1992). Stampfl (1979) developed a code of ethics for consumers while Schubert (1979) developed strategies for combating consumer abuse. The majority of the current research conducted on business ethics has concentrated on sellers and marketing related activities with a notable lack of attention to understanding ethics from the consumers' perspective (Muncy and Vitell, 1992). In any transaction, both suppliers and consumers are key components of marketing exchanges. If research on ethics focused only on suppliers, it will result in a deficient and biased understanding of the subject matter (Vitell and Muncy, 1992). Millions of dollars have been lost in counterfeiting and piracy; the impact of globalisation and the invention of the internet accelerated and highlighted consumer ethical issues, which in turn aroused researchers' attention such that they have shown increasing interest in the topic during the last two decades (Chatzidakis and Mitussis, 2007).

If Bernstein (1985, p.24) was right that consumers are "outdoing big business and the government at unethical behaviour" and assuming that this situation has not improved in recent years, there is a definite need to examine the ethical decision-making behaviour of consumers. An enhanced understanding of the behaviour may help devising strategies to minimise resulting detrimental effects. The key challenges in the research of consumer ethics are to find out the factors that have correlation with ethical issues and to determine the attitudes of consumers towards certain ethical behaviours (Muncy and Vitell, 1992; Depaulo, 1987). Another important issue is the relationship between consumer ethics and factors of consumption phenomenon, such as materialism and compulsive buying ( $\mathrm{Lu}$ and $\mathrm{Lu}, 2009$; Muncy and Eastman, 1998). Empirical evidence indicates that materialism is negatively correlated with consumers' ethical standards (Muncy and Eastman, 1998). However, Vitell, Singhapakdi and Thomas (2001) found that materialism was not related to ethical judgment when they explored the relationship among consumers in the USA. Analytic results of a study in Indonesia indicated that their people possessing high materialism and relativism were more likely to be involved in questionable practices, although those practices are still within the legal boundary ( $\mathrm{Lu}$ and $\mathrm{Lu}, 2009$ ). Controversy exists over the relationship between materialism and consumers' ethical behaviour; and therefore more research is needed to study this relationship.

Consumer behaviour is mainly related to acquiring, using and disposing of goods and services. All aspects of such behaviour have an integral ethical component (Vitell, 2003) and previous studies indicated that consumers' judgments of these behaviours are not simple and straight-forward. For example, their judgment may be different depending on whether the focus is on the buyer or the seller (DePaulo, 1987). Grove, Vitell and Strutton (1989) found that consumers tend to neutralise and justify their non-normative practices by denial tactics. Muncy and Vitell (1992) revealed three factors affect consumers' perceptions regarding the ethical content of situations: the locus of faults, the presence of deceptions on the part of consumers, and the degree of harm. They also found that consumers act more ethically if they have a positive attitude towards business (Vitell and Muncy, 1992). 
Understanding consumers' unethical behaviour and its relationship with some prominent factors is important as the behaviour causes millions of dollars of losses to governments and businesses. Enhanced understanding may help government formulate policies both in education and legal enforcement to mitigate dysfunctional behaviour. Furthermore, consumers' attitude towards business has implication for business practices; by being socially responsible, businesses can minimise losses and build a good corporate image.

\section{Literature Review}

Business ethics is an important construct attracting scholars' attention for several decades; considerable conceptual and empirical work has been devoted to the marketing discipline due to increasing awareness from the government and public with regard to the environmental and social effects of business operations (Hunt and Vitell, 1992; Ferrel, Gresham and Fraedrich, 1989; Hunt and Vitell, 1986; Ferrel and Gresham, 1985). Marketing is where many ethical problems lie since it is the predominant exchange platform through which transactions between sellers and buyers take place (Vitell and Festervand, 1987; Brenner and Molander, 1977; Baumhart, 1961). Though most of the research examines ethics from the sellers' side, marketers are not more Machiavellian than other members of society (Al-Khatib, 1996).

Comparatively, little research has been conducted on consumer ethics towards consumers' perception of their own ethical behaviour (Muncy and Vitell, 1992; Depaulo, 1987). Consumers are important participants in any transactions; downplaying their role in ethics research is analogous to missing an important piece of the puzzle, without which it is not possible to comprehend the whole picture. Moreover, some previous studies found that consumers' decision-making and behavior might be related to some demographic factors, although the impact still remains controversial (Rallapalli, Vitell, Wiebe and Barnes, 1994; Muncy and Vitell, 1992; Vitell, Lumpkin and Rawwas, 1991). It is therefore important to study how consumers perceive the issues relating to ethical content and the moderating impact of demographic variables on consumers' ethical decision-making.

\section{Consumer Ethics}

It could be construed that the term 'consumer ethics' simply means looking at ethics from the perspective of consumers. However, behaviour of consumers could not be studied separately and independently; it needs to be considered in relation to other stakeholders, such as sellers, and behaviour itself, which can be rational, irrational, cognitive or affective, is influenced by the attitude, intention, psychological state, norm, situational context and religious background of individuals (Ajzen, 1991; Hunt and Vitell, 1992, 1986; Fukukawa, 2002).

In researching consumer ethics, an understanding of Machiavellianism enables the gaining of a better insight of the issue. Machiavellianism (Machiavelli, 1531) is a label for using immoral ways of accomplishing one's objectives. It is defined as attending to one's interests more than to others. There is a relative lack of affection in interpersonal relationships, gross psychopathology, and ideological commitment. Individuals with high level of Machiavellianism usually do not pay regard to conventional morality and are more likely to engage in unethical behaviour if their self-interest is affected (Geis and Moon, 1981). 
Singhapakdi and Vitell (1990) found that high Machiavellian individuals tend to be less ethically sensitive than low Machiavellian individuals with respect to various aspects of ethical behaviour.

\section{Hunt and Vitell's General Theory of Marketing Ethics}

Among the three major comprehensive theoretical models (Hunt and Vitell, 1992, 1986; Trevino, 1986; Ferrel and Gresham, 1985) concerning ethical issues in marketing and business, only the Hunt-Vitell model is appropriate for individual consumers since the other two are oriented towards business professionals.

Hunt and Vitell's model (1992) incorporates existing theories and subject them to different contextual influences. It represents one of the most established models within the broader business ethics scenario (O'Fallon and Batterfield, 2005) including computer ethics such as illegal downloading of computer software by professionals (Thong and Yap, 1998). As depicted in the Hunt-Vitell model $(1992 ; 1986)$, the way an individual perceives an ethical issue affects the various alternatives that could be used to resolve the issue. Two major evaluations take place; they are the deontological and teleological evaluations. The former focuses on the intention behind behaviours while the latter focuses on the consequences.

Deontological evaluation is based on personal values and beliefs which are subjective and not easily validated. Individuals would try to evaluate whether the behaviour or alternatives are right by benchmarking their own set of norms. This set of norms represents an individual's own personal values and beliefs that include general beliefs as well as situation-specific beliefs. Another major evaluation, teleological evaluation is more result oriented. An individual will choose the most desirable and beneficial alternative, albeit it may be the least ethical. So the key issue in consumer assessment is that the decision will provide benefits in an overall sense. A particular behaviour is considered the most ethical if there is a greater balance of good over bad compared to the other alternatives.

Hunt and Vitell $(1992 ; 1986)$ revealed that an ethical decision process begins with a consumer perceiving an ethical problem and continues with the consumer combining a deontological and a teleological evaluation to arrive at a judgment or an attitude about the ethical problem (Chatzidakis and Mitussis, 2007). The ethical judgment may differ from the original intentions after examination of the probable consequences, and an individual's past behaviour and feedback on the actual consequences may affect their future behaviour.

\section{Muncy and Vitell's Study}

Among the early empirical studies was that of Muncy and Vitell (1992). The survey consisted of 20 measurements with potential ethical concerns which measured the extent consumers agreed or disagreed with certain questionable practices. The research also tied consumer beliefs to demographic and attitudinal information. The results, from 569 U.S. households indicated four basic dimensions of consumer ethical beliefs, they are active benefit-seeking activities which are illegal, passive benefit-seeking activities which are questionable, deceptive legal practices and no harm, no foul. 
The first two dimensions relate to ethical situations where the buyers are benefited; the main difference between the two situations relates to whose actions are responsible for the benefit. The first dimension includes all behaviours in which consumers actively seek for the benefits at the expense of the sellers; the benefit received is as a result of the consumer's proactive behavior (e.g. changing a price tag or drinking a can of beer without paying for it). In contrast, the second dimension represents cases where consumers do nothing to receive the benefit (e.g. not saying anything upon receiving benefits to which they are not entitled). The third dimension has been labeled deceptive practices, which encompass situations where consumers in some way deceive the sellers, and is the most difficult situation to interpret (e.g. returning merchandise after using it). The last dimension refers to situations where consumers may not perceive a direct, attributable, micro-level harm; although such harm actually does occur, consumers may not look deep enough to see it. This is called no harm, no foul and refers to situations such as copying a musical album or downloading computer software instead of buying it.

Vitell (2003) found that consumers tended to consider illegal activities that benefited them to be most unethical; proactive activities were considered to be more unethical than passive ones. And, deceptive practices were not perceived as being as unethical as illegal passive activities. Furthermore, the consumers who responded to Vitell's survey considered computer downloading activities not to be unethical because they caused no harm to others. This finding has implications for the record and computer software industries in particular, since they lose billions of dollars in sales each year because people think it does not cause any harm to others that they 'borrow' rather than purchase their material. Moreover, research found that this behaviour is culture-specific ( $\mathrm{Lu}$ and $\mathrm{Lu}, 2009$; Chan, Wong and Leung, 1998).

\section{Cross-cultural Studies}

Lascu (1993) examined whether Muncy and Vitell's set of consumer ethics measures was appropriate for use in a cross-cultural context and concluded, together with a panel of expert assessors, that it was. Among the cross-cultural studies undertaken using these measures, there were many research studing different countries or cities about consumer ethics (Rawwas, Vitell and Al-Khabib, 1994; Rawwas, Strutton and Johnson, 1996; Swaidan, 1999). These results indicate that environment and situational context may play a major role in affecting consumers' perceptions. Rawwas, Patzer and Klassen (1995) conducted a cross-cultural study comparing consumers in Northern Ireland to those in Hong Kong. They hypothesised that those subjected to a more chaotic form of colonialism (the Northern Irish consumers) would be more accepting of questionable consumer practices than those subjected to a more stable form of colonialism (the Hong Kong consumers). Results indicated that there is no difference between Northern Irish consumers and Hong Kong consumers in their general ethical beliefs; they were about the same in terms of idealism and relativism with the Irish only slightly higher in terms of Machiavellianism.

According to Vitell (2003), despite differences in the foci of these various studies, there is general support for the basic tenets and the factor structure of the consumer ethics measures 
proposed by Muncy and Vitell (1992). In particular, the previous study conducted in Hong Kong lends support for the use of the measures in this study. Vitell and Muncy (2005) compared differences in ethical perspectives between student and non-student consumers. Results from their questionnaire survey indicated that a significant number of people see a fundamental difference between "an act such as drinking a can of soda in a supermarket without paying for it" and "recording an album instead of buying it"; they think the former is wrong but see nothing wrong with the latter despite the nature of two acts being similar. The findings also indicated that students are more acceptable of questionable consumer practices than non-students.

$\mathrm{Lu}$ and $\mathrm{Lu}$ (2009) conducted an exploratory study on materialism and consumer ethics of Indonesians. Results indicated that Indonesians with high levels of materialism and relativism are more likely to engage in actions that are questionable but legal. Revenue losses in Indonesia related to counterfeiting amounted to US\$183 million in 2004, which is a significant amount. Similarly in Hong Kong, the government seized pirated CDs/DVDs with a value of approximately HK\$180 million in 2001 (Kwong, Yau, Lee, Sin and Tse., 2003). This suggests that a study of the questionable behaviour of consumers in Hong Kong would be of value to practitioners.

\section{Culture of Chinese People in Hong Kong}

Chan et al. (1998) explored the ethical belief of Chinese consumers in Hong Kong and arrived at findings similar to those of previous studies in some aspects, especially those of Freestone and Mitchell (2004) who found that consumers are more tolerant of questionable actions representing cases of copy-right violation. This may explain why so many consumers in Hong Kong ignore intellectual property rights and buy counterfeit products (Chung, 1994). Chan et al.'s study also reinforced findings of previous studies that respondents with a more positive attitude towards business tend to be less tolerant of 'passively benefiting' behaviour. The roles of norm and situational context are particularly prominent in Chinese culture and peer pressure plays a significant role in judging whether a particular behaviour is ethical or not.

Chinese people tend to have a strong cultural motivation towards group conformity and 'face saving' (Hofstede, 2002), which may be due to the collective culture. Situational context and group norms may play an important role, and Chinese consumers may have separate standards for their public and private lives. For example, in public they may have high ethical standards to obvious illegal behaviour, such as opening a packet of peanuts and taking some away but in private they may have a lower standard and regard a less observable illegal behaviour as questionable only (Chan et al., 1998).

\section{Materialism}

Materialism is another construct gaining increasing attention from researchers (Muncy and Eastman, 1998). Both materialism and consumer ethics are consumption phenomena and an association may exist between the two constructs that may be another facet of consumer behaviour worth exploring. 
Unlike consumer ethics, materialism was defined by different scholars with different perspectives. Ward and Wackman (1971, p. 422) defined "materialism as an orientation which views material possessions and money as being important for personal happiness and social progress." Belk (1985, p.265) defined "materialism as comprising the personality traits of possessiveness, envy and non-generosity, and as reflecting the importance a consumer attaches to worldly possessions." Belk assumed "possession is the central role in a materialistic person's life, providing the greatest source of satisfaction and dissatisfaction." In the study from Richins and Dawson (1992) stressed that material possessions is important to centrality, happiness and success.

Acquisition centrality suggests that those who score higher on this component make possessions the focus of their lives. Acquisition in the pursuit of happiness suggests that possessions are vital for a materialist consumer's well-being and satisfaction in life. Possession-defined success relates to the role that possessions play as evidence of success (Richins and Dawson, 1992; Belk, 1985; Ward and Wackman, 1971). Thus, Richins and Dawson (1992) conceptualized that value of possessions for a materialistic person lies in their ability to confer status and to project a desired self image.

All definitions relate materialism to possession, happiness and social status and imply that acquisition or possession is the focus of lives and an important means to pursue happiness. In contrast, Belk (1985) argued that those scored high on materialism scale, are less happy in life and contended that materialism is also the greatest source of dissatisfaction. These controversial arguments raise research interests about the dark side of materialism.

\section{Societal and Ethical Problems caused by Materialism}

Materialism, the belief that material possessions can lead to greatest source of satisfaction in life, is causing societal and ethical problems (Muncy and Eastman 1998; Belk, 1985). Research findings suggested that materialistic tendencies are related with reduced well-being such as lack of affection to others (Kasser, 2002; Kasser and Ryan, 2001).

Rudmin and Richins (1992) argued that materialism is questionable from an ethical perspective. Barrett (1992) associated certain types of unethical behaviour with greater amounts of materialism. Belk (1988) related greater materialism to an inevitable loss of a sense of community, which might in turn make people less sensitive to behaviours that might negatively affect others and make them less willing to share their possessions with charity, friends or family (Richins and Dawson, 1992).

More materialistic consumers might be willing to compromise or bend ethical rules to gain possessions (Richins and Dawson, 1992; Ferrell and Gresham, 1985). Reitman (1996) argued that adolescent materialism was driving the proliferation of Japanese teen prostitution. Recently, there have been a number of news reporting cases of conducting prostitution by teenagers in Hong Kong and the key driving force behind it is to obtain sufficient money to purchase goods. New Economics Foundation, a British non-profit making organization conducted a survey in 2009 on the degree of happiness of people in 143 countries and complied a happiness index. Hong Kong's happiness index was 41.6 and ranked 84; even 
after Iraq and Iran (Ming Pao Daily, 2009). It seems the higher degree of materialistic possession in Hong Kong is associated with reduced happiness.

\section{Cross-cultural Studies}

A number of cross-cultural studies have been conducted on the materialism levels of people in the United States, Europe and Asia. Ger and Belk (1996) conducted a cross-cultural study on 12 nations in which they found that Romanian students were the most materialistic and Swedes were the least. The researchers considered that their findings support the hypothesis that materialism is highest in countries which are socially and economically dynamic. In studies conducted by Eastman, Fredenberger, Campbell and Calvert (1997) and Clarke and Micken (2002) on student groups, they discovered that Mexicans are the least materialistic. The reason may be due to the collectivistic nature of their culture. Eastman et al. (1997) also found that Chinese students were the most materialistic. Schaefer, Hermans and Parker (2004) found a significant difference in materialism across groups of teenagers from China, Japan and the United States. The different cultures between the West and the East, and the difference between the cultures in China and Japan, may help explain the differences.

\section{Demographic Variables}

Consumers' ethical decision-making may be related to certain demographic characteristics (Muncy and Vitell, 1992). Age tends to exhibit an inverse relationship to consumer ethics with older respondents exhibiting a higher level of ethical concern than younger respondents (Muncy and Vitell, 1992). Vitell et al. (1991) investigated the ethical beliefs of elderly consumers and found that though they were generally more ethical than the younger consumers, they exhibited a great diversity in their ethical beliefs. Gender was linked by more than one study to ethical beliefs, but the results are certainly not definitive.

Consumers possessing lower income or education level are more ethical (Muncy and Vitell, 1992). Kwong et al. (2003) showed that there was no evidence that customers buying pirated CDs/DVDs have a lower income and a lower education, which reinforced the findings of Muncy and Vitell (1992). However, Ang, Cheng, Lim and Tambyah (2001) found that males and those with lower incomes were more likely to be in favour of piracy.

Some empirical studies revealed controversies in relation to the impact of demographic factors on consumer ethics (Singhapakdi and Rawwas, 1998; Freestone and Mitchell, 2004) and therefore further studies in this respect seem necessary.

\section{Research Framework and Hypotheses}

Although the ethical judgment of consumers in the United States and other industrialised countries has received considerable attention, it has rarely been addressed in Asian countries (Ang et al., 2001; Rawwas, Patzer and Vitell, 1998). Asian consumers have gained a bad reputation for trading counterfeited products; in particular, Hong Kong has a reputation as a 'moral jungle' where no ethical standards exist (McDonald and Zepp, 1988). Hong Kong is notorious for selling and buying of pirated CDs/DVDs and the problem of piracy has become more serious since the advancement of copying technology. In 2001, the Hong Kong 


\section{Macrothink}

Journal of Management Research

ISSN 1941-899X

2012, Vol. 4, No. 2

Government seized pirated CDs/DVDs, valued at HK\$180 million (Kwong et al., 2003). Part of this problem is that consumers consider that buying pirated CDs/DVDs is equivalent to self-replication of the software and therefore is not illegitimate ( $\mathrm{Lu}$ and $\mathrm{Lu}, 2009$ ).

As there have been only limited studies to examine the pirating phenomenon in Hong Kong, five research questions to be addressed by this study were:

1. What are the ethical judgments of consumers in Hong Kong?

2. What are the attitudes of consumers towards material goods?

3. Is there any impact of materialism on consumer ethics?

4. Would gender difference lead to different degree of materialism?

5. Would age, income or education moderate the relationship between materialism and consumer ethics?

\section{Research Framework}

Based on the review of relationship between consumer ethics and materialism, and demographic factors as moderators, a research framework is shown as Figure 1 below.

Independent

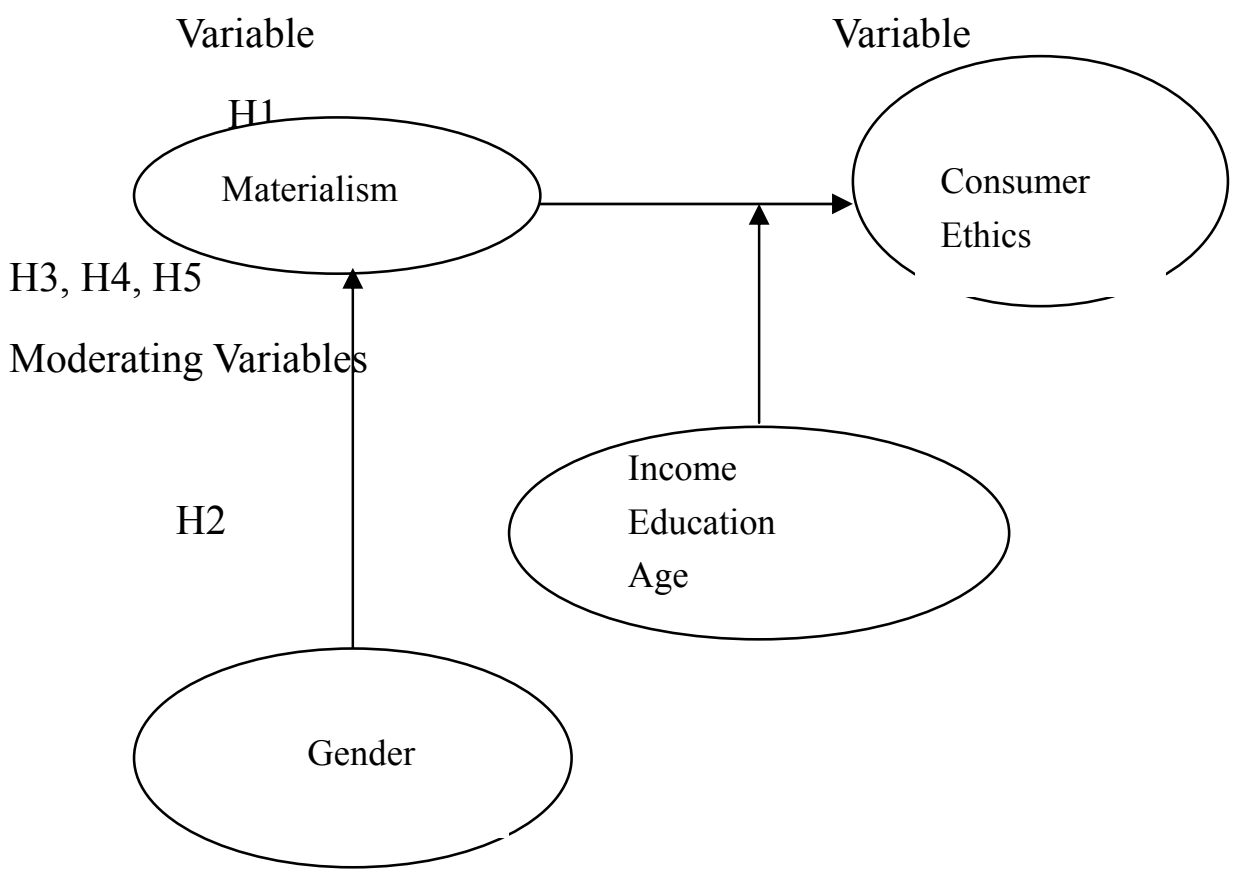

Figure 1. Research Framework

\section{Measurements}

Measurements used in Muncy and Vitell's model (1992) were adapted as dependent variables, and the seven-item measurement of materialistic attitudes (MMA) used by Schaefer et al. (2004) were adopted as independent variables. 


\section{Ml Macrothink}

\section{Dependent Variables}

Measurements of Muncy and Vitell (1992) were used in this study to measure consumers' ethical beliefs. To encourage a good response rate, a concise yet comprehensive questionnaire was designed using only 9 of the 20 measurements. Although a smaller number of variables are used, they are nevertheless representative since they cover the same four consumer ethical dimensions utilized by Muncy and Vitell in their 1992 study. Chan et al. (1998) examined the ethical beliefs of consumers in Hong Kong by adapting Muncy and Vitell (1992)'s ethical belief measurements. However, as the original measurements were for the most part based on the culture and lifestyle generally found in the United States (Lascu, 1993), Chan et al. modified and replaced a few measurements to reflect the frequently-encountered questionable behaviours in Hong Kong. The replacement measurements were also included in this research. The 9 belief measurements are illustrated in Table 1 below.

Table 1. Measurements used for Consumer Ethics Survey

\begin{tabular}{|l|l|}
\hline Four Consumer Ethical Dimensions & Measurements \\
\hline $\begin{array}{l}\text { Proactively benefiting at the expense of the } \\
\text { Seller. }\end{array}$ & $\begin{array}{l}\text { 1. Changing price tags on merchandise in a retail store. } \\
\text { 2. A young adult uses a child or elderly Octopus Card. }\end{array}$ \\
\hline $\begin{array}{l}\text { Passively benefiting at the expense of the } \\
\text { seller. }\end{array}$ & $\begin{array}{l}\text { 4. Getting too much change and not saying anything. } \\
\text { Deceptive practices. }\end{array}$ \\
$\begin{array}{l}\text { 6. Using an expired coupon. } \\
\text { on sale. }\end{array}$ \\
\hline No harm, no foul. & $\begin{array}{l}\text { 8. Recording a musical album instead of buying it. } \\
\text { 9. Using computer software or games that you did not buy. }\end{array}$ \\
\hline
\end{tabular}

Source: Chan et al. (1998); Muncy and Vitell (1992)

\section{Independent Variables}

A seven-item measurement of materialistic attitudes (MMA) used by Schaefer et al. (2004) was adapted as the independent variables for this research. The measurements were adapted from prior studies by Wackman, Reale and Ward (1972) and Moschis and Churchill (1978) and modified by Schaefer et al. (2004) for improved applicability in the Asian context. The measurement of materialism is shown in Table 2 below. 
Table 2. Measurements used for Measuring Materialism

\begin{tabular}{|l|l|}
\hline Roles & Measurements \\
\hline $\begin{array}{l}\text { A seven-item measure of attitudes towards material possessions, such as } \\
\text { possession-defined success. }\end{array}$ & $\begin{array}{l}\text { 1. It is really true that money } \\
\text { can buy happiness. } \\
2 . \text { My dream in life is to be able } \\
\text { to own expensive things. } \\
3 . \text { People judge others by what } \\
\text { they own. } \\
4 . \text { I buy some things that I } \\
\text { secretly hope will impress others. } \\
5 . \text { Owning the right things is } \\
\text { the most important thing in life. } \\
6 . \text { Others judge me by the kinds } \\
\text { of things I own. } \\
7 . \text { People will like me more if I } \\
\text { own the right things. }\end{array}$ \\
\hline
\end{tabular}

Source: Schaefer, Hermans and Parker, 2004

The following two hypotheses were generated to study materialism and consumers' ethical judgments in Hong Kong.

Hypothesis 1: There is positive relationship between materialism and consumers' unethical behaviour.

Hypothesis 2: Females are more materialistic than males.

It is reasonable to postulate hypothesis 1 to be a positive relationship between materialism and consumers' unethical behavior because the most recent research on the relationship conducted in the Asian context showed a positive relationship ( $\mathrm{Lu}$ and $\mathrm{Lu}, 2009$ ) and although other research results in the western countries were controversial showing no or negative relationship. As the present research was conducted in Hong Kong which is also in the Asian context, therefore the study would like to test that a positive relationship might exist between materialism and consumer ethics.

\section{Moderating Variables}

Extensive research has been conducted relating to the effect of demographic factors on the relationship between materialism and consumer ethics (Kwong et al., 2003; Muncy and Vitell, 1992) and materialism (Goldberg, Gorn, Peracchio and Bamossy, 2003; Lundstrom and White, 1999; Achenreiner, 1997). Researches have been conducted on materialism and consumer ethics (Lu and Lu, 2009; Muncy and Eastman, 1998) but the moderating effect of demographic factors on the relationship has not been studied in these researches. The following three hypotheses therefore address this issue. 
Hypothesis 3: Age positively moderates the relationship between materialism and consumer ethics.

Hypothesis 4: Income positively moderates the relationship between materialism and consumer ethics.

Hypothesis 5: Education positively moderates the relationship between materialism and consumer ethics.

\section{Research Design}

A research design provides a framework for collecting and analysing data (Bryman, 2004). This study applied cross-sectional research design.

\section{Data Collection Method}

There are several data collection methods used in quantitative research methodology, including self-administered questionnaire surveys, structured interviews, and focus groups. The purpose of this study was to examine the impact of materialism on the unethical behaviour of consumers. The target participants were adult students studying courses at diploma, bachelor, master and doctoral levels, and were mainly sourced from the Hong Kong Management Association (HKMA). In order to achieve a high response rate, a self-administered questionnaire survey was conducted during class, which ensured that questions could be explained if necessary. Respondents were expected to answer the questions freely and honestly with the whole process taking approximately 10 minutes.

\section{Sampling}

This study used a sampling frame of adult students in Hong Kong to examine the relationship between materialism and consumer ethics. In consideration of the research objective, time and resources constraints, requirements and common practices in consumer and marketing research, convenience sampling was chosen for this study. Although the survey sample was restricted to adult students in Hong Kong and convenience sampling method is used, there is a limitation to the generalization of the results to the populations in Hong Kong and other countries. This research has the contribution in addressing the phenomenon in Hong Kong which has a unique culture which combines that of the East and the West. The researcher would like to draw attention to the subject matter hoping that more future research will be done to examine this.

Moreover, educational researchers commonly employ non-probability sampling, such as convenience sampling, by using available classes as samples (Sylvia-Bobiak and Caldwell, 2006; Garland, Kim, Lancster and Ponsford, 2006; Ng, 2005). Violet, Garland and Pendleton (1986) argued that using non-probability sampling does not necessarily diminish the contribution of a study. Convenience sampling is useful if purpose of the study is to find the existence of relationship between variables. The sampling size of 303 was justified by previous similar studies conducted on consumer behaviour. Rawwas and Singhapakdi (1998) selected a group of 288 teenagers for a study related to consumers' ethical beliefs. Chan, Wong and Leung's study (1998) of ethical belief of Chinese consumers in Hong Kong was 
conducted on 242 part-time and full-time students in Hong Kong.

\section{Measurement of Variables}

Multiple-indicators were used to measure the two variables of materialism and consumer ethics with respondents being asked to answer a number of questions for each variable. One indicator may not have been representative enough for measuring one variable for every respondent and might not have been strong enough to cover all the underlying issues (Bryman, 2004).

Cronbach's alpha value, a common technique was used to test internal reliability (Bryman, 2004). If Cronbach's alpha value for a measuring item is 1 , it denotes perfect internal reliability; an alpha value of 0 means no internal reliability and an alpha value of 0.7 shows an acceptable level of internal reliability (Nunnally, 1978). Construct validity is concerned with whether the quality of the results obtained by the measuring scales fit the theories and was tested in this research by using exploratory factor analysis and correlation analysis for confirming the dimensions of the concept (Cavana Delahaye and Sekaran, 2001).

Respondents to the survey were requested to rate statements relating to their feelings of possessing material goods on a five-point Likert rating scale, with the anchor points from 'strongly agree' to 'strongly disagree' and the middle point being 'Neutral'. Participants were also asked to reveal their judgment about certain consumer behaviours. The respondents were requested to rate ethical belief measurements as to whether they perceived these actions as being "wrong (unethical)" on a 5-point Likert scale with the anchor points being "strongly believe it is wrong" to "strongly believe that it is not wrong" and the middle point being "neutral".

\section{Data Analysis}

The data were analysed by using descriptive analysis, exploratory factor analysis, Pearson product moment correlation, independent samples $\mathrm{t}$-test, and multiple regression analysis. Descriptive analysis was carried out to view average and spread of the data. This helped to identify missing values and data that have been keyed in wrongly, and describes the distribution of continuous data. As a normal distribution is favoured for most analyses, it is important to apply descriptive analysis at a primary stage in order to have an overview of the data distribution. The mean scores, frequency and spread of distribution for each question were computed and presented, and their corresponding meanings were described. The descriptive analysis for these was carried out using mean, standard deviation, skewness and kurtosis, which Shao (2002) claimed make sense when interval scales are used. The mean, standard deviation, skewness and kurtosis can indicate if the distribution is normal or symmetrical. The data should be distributed normally in order to carry out further analysis.

This study used exploratory factor analysis (EFA) to measure the validity of the data using the two constructs of consumer ethics and materialism. Exploratory Factor Analysis was used because this research studied whether there is a relationship between consumer ethics and materialism. Although this study followed a prior study, it used only some of the original variables. A number of new variables were introduced to reflect the local context, e.g. 
Octopus Card. Therefore EFA was used instead of Confirmatory Factor Analysis. Measurement assessment for this study was conducted by using EFA to measure convergent and discriminant validity, and Cronbach's alpha $(\alpha)$ for measuring internal consistency and reliability. Cronbach's alpha was used to measure the inter-item consistency and reliability of the multi-item scales of each independent and dependent variable. Reliability analysis was conducted for each construct with correlations applied. The closer the reliability coefficient gets to 1.0 , the better.

A satisfactory internal reliability is achieved if the Cronbach's alpha value is greater than 0.7 (Cavana et al., 2001), and items are well correlated within the scale if the Pearson correlation coefficients have a high value. If the loadings of all items under each construct are greater than 0.5, and Cronbach's alpha value is greater than 0.7, the items in a construct are proved to be a single-factor structure for that construct (Hair, Black, Babin, Anderson and Tatham, 2006; Nunnally, 1978). Secondly, Bartlett's test of Sphericity was examined to identify if inter-correlation existed. Chi-Square $\left(\chi^{2}\right)$, degree of freedom and $p$-value were considered in the examination of the inter-correlation between the hypotheses.

To enable EFA for attitude toward consumer ethics, Principal Component Analysis extraction was used with varimax rotation, suppressing factor loading below 0.5 as there were 278 valid samples for this study. Pearson product moment correlation and simple linear regression (SLR) were carried out to test the positive effect of hypothesis H1. A positive effect is proved if the correlation coefficient between the independent variable and the dependent variable in the hypothesis is positive. The hypothesis is supported if the significant value in the correlation testing is less than 0.05 (one-tailed test).

Independent samples t-test (one-tailed test) was used to test hypothesis $\mathrm{H} 2$ to reveal whether females are more materialistic than males. Two Independent t-test were used because the independent variable is categorical while the dependent variable is metric. It compared the mean of materialism of females with that of males. Firstly, the assumption of homogeneity of variance was tested by using Levene's test. Secondly, depending on the result of the Leven's test, the result of the t-test could be determined accordingly.

Multiple regression analysis refers to a regression model with two or more independent variables and is used to find out how the variance in the dependent variable can be explained when several independent variables are theorized to influence it simultaneously (Hair, Anderson, Tatham and Black, 1995). It was conducted to test hypotheses H3, H4 and H5 in respect of the moderating effect (Baron and Kenny, 1986) of demographic variables of income, age and education on the relationship between materialism and consumer ethics. Moderating variables are introduced when there is an unexpected weak or inconsistent relationship between an independent and dependent variable.

\section{Results and Analysis}

\section{Characteristics of the Sample}

Descriptive statistics provide fundamental classifications and obtain an understanding of the data. By reducing and simplifying a large set of information to a smaller set in the process, it 
helps the researcher obtain a more manageable amount of data without losing the essential information and provides an overview of those who responded to the survey (Smith and Glass, 1987). Table 3 below provides a summary of the demographic variables of the respondents. Given the discrete nature of the data, frequency and percentage are used for the descriptive analysis and presented as bar charts.

Table 3. Descriptive Statistics - Demographic Variables

\begin{tabular}{|c|c|c|c|}
\hline Demographic Variables & Measures & Frequency & Percentage \\
\hline \multirow[t]{2}{*}{ Gender } & Male & 134 & $48.9 \%$ \\
\hline & Female & 140 & $51.1 \%$ \\
\hline \multirow[t]{5}{*}{ Age } & 18 to 20 years & 14 & $5.0 \%$ \\
\hline & 21 to 25 years & 139 & $50.0 \%$ \\
\hline & 26 to 30 years & 60 & $21.6 \%$ \\
\hline & 31 to 35 years & 35 & $12.6 \%$ \\
\hline & 36 years and above & 30 & $10.8 \%$ \\
\hline \multirow{5}{*}{$\begin{array}{l}\text { Monthly Income } \\
\text { (HK Dollars) }\end{array}$} & Less than 4,000 & 61 & $22.5 \%$ \\
\hline & $4,000-8,000$ & 20 & $7.4 \%$ \\
\hline & $8,001-10,000$ & 57 & $21.0 \%$ \\
\hline & $10,001-15,000$ & 68 & $25.1 \%$ \\
\hline & 15,001 and above & 65 & $24.0 \%$ \\
\hline \multirow[t]{5}{*}{ Education } & Diploma/Advanced & 146 & $52.5 \%$ \\
\hline & Diploma & 0 & $0 \%$ \\
\hline & Bachelor Degree & 85 & $30.6 \%$ \\
\hline & Master Degree & 38 & $13.7 \%$ \\
\hline & Doctoral Degree & 9 & $3.2 \%$ \\
\hline
\end{tabular}

\section{Descriptive Analysis of the Measuring Variables}

A descriptive analysis for each of the measuring variables in this research is discussed in the following sections. Mean, standard deviation, skewness, and kurtosis are used for descriptive analysis because of the continuous nature of the data collected for consumer ethics and materialism.

\section{Materialism}

Table 4 shows the results of the 278 usable questionnaires; the minimum value of ' 1 ' and maximum value of ' 5 ' show that there is no error in data entry. The average score for attitude toward possessing material goods is slightly less than 3, which indicates that respondents were more inclined to agree that material possessions can lead to happiness and feelings of centrality. The standard deviations are all lower than the mean values and there is a good distribution. Consistent with the average values which show more "agreeing," the positive skewness for all items shows that the responses are more toward agreeing with the statements. Kurtosis is negative but less than 1, it shows a fairly good distribution. Results indicate that respondents are slightly more favourable towards material possession. There is an exception to the statement 'MAT2: My dream in life is to be able to own expensive things'; the score of 
this statement is slightly more than 3 . This indicates that respondents disagree with the importance of owning expensive things.

Table 4. Descriptive Statistics - Materialism

\begin{tabular}{|c|c|c|c|c|c|c|c|c|c|}
\hline \multirow[t]{2}{*}{ Questions } & \multirow{2}{*}{$\begin{array}{l}\mathbf{N} \\
\text { Stat. }\end{array}$} & \multirow{2}{*}{$\begin{array}{l}\text { Min. } \\
\text { Stat. }\end{array}$} & \multirow{2}{*}{$\begin{array}{l}\text { Max. } \\
\text { Stat. }\end{array}$} & \multirow{2}{*}{$\begin{array}{l}\text { Mean } \\
\text { Stat. }\end{array}$} & \multirow{2}{*}{$\begin{array}{l}\text { Std. } \\
\text { Deviation } \\
\text { Stat. }\end{array}$} & \multicolumn{2}{|c|}{ Skewness } & \multicolumn{2}{|c|}{ Kurtosis } \\
\hline & & & & & & Stat. & $\begin{array}{l}\text { Std. } \\
\text { Error }\end{array}$ & Stat. & $\begin{array}{l}\text { Std. } \\
\text { Error }\end{array}$ \\
\hline $\begin{array}{l}\text { MAT1: } \\
\text { It is really true that } \\
\text { money can buy } \\
\text { happiness. }\end{array}$ & 277 & 1 & 5 & 2.81 & 1.021 & 0.461 & 0.146 & -0.368 & 0.292 \\
\hline $\begin{array}{l}\text { MAT2: } \\
\text { My dream in life is to be } \\
\text { able to own expensive } \\
\text { things. }\end{array}$ & 277 & 1 & 5 & 3.11 & 0.955 & 0.076 & 0.146 & -0.733 & 0.292 \\
\hline $\begin{array}{l}\text { MAT3: } \\
\text { People judge others by } \\
\text { what they own. }\end{array}$ & 278 & 1 & 5 & 2.54 & 0.913 & 0.717 & 0.146 & -0.052 & 0.291 \\
\hline $\begin{array}{l}\text { MAT4: } \\
\text { I buy some things that I } \\
\text { secretly hope will impress } \\
\text { others. }\end{array}$ & 278 & 1 & 5 & 2.82 & 0.820 & 0.257 & 0.146 & -0.526 & 0.291 \\
\hline $\begin{array}{l}\text { MAT5: } \\
\text { Owning the right things } \\
\text { is the most important } \\
\text { thing in life. }\end{array}$ & 276 & 1 & 5 & 2.34 & 0.972 & 0.718 & 0.147 & 0.118 & 0.292 \\
\hline $\begin{array}{l}\text { MAT6: } \\
\text { Others judge me by the } \\
\text { kinds of things I own. }\end{array}$ & 278 & 1 & 5 & 2.90 & 0.824 & 0.196 & 0.146 & -0.539 & 0.291 \\
\hline $\begin{array}{l}\text { MAT7: } \\
\text { People will like me more } \\
\text { if I own the right things. }\end{array}$ & 278 & 1 & 5 & 2.71 & 0.963 & 0.189 & 0.146 & -0.873 & 0.291 \\
\hline Valid N (listwise) & 274 & & & & & & & & \\
\hline
\end{tabular}

\section{Consumer Ethics}

The descriptive analysis of consumer ethics is shown in Table 5. The average score is around 3 or slightly more than 3 showing that respondents were more inclined to agree that the unethical consumer behaviours were wrong. The distribution is fairly normal since the standard deviations are all lower than the mean values. Skewness for all items is negative, showing a negatively skewed distribution. This is consistent with the average values which show more respondents who "agree that the unethical behaviours are wrong". Kurtosis is also negative, and this is a fairly good distribution. 
Table 5. Descriptive Statistics - Consumer Ethics

\begin{tabular}{|c|c|c|c|c|c|c|c|c|c|}
\hline \multirow[t]{2}{*}{ Questions } & \multirow{2}{*}{$\begin{array}{l}\mathbf{N} \\
\text { Stat. }\end{array}$} & \multirow{2}{*}{$\begin{array}{l}\text { Min. } \\
\text { Stat. }\end{array}$} & \multirow{2}{*}{$\begin{array}{l}\text { Max. } \\
\text { Stat. }\end{array}$} & \multirow{2}{*}{$\begin{array}{l}\text { Mean } \\
\text { Stat. }\end{array}$} & \multirow{2}{*}{$\begin{array}{l}\text { Std. } \\
\text { Deviation } \\
\text { Stat. }\end{array}$} & \multicolumn{2}{|c|}{ Skewness } & \multicolumn{2}{|c|}{ Kurtosis } \\
\hline & & & & & & Stat. & $\begin{array}{l}\text { Std. } \\
\text { Error }\end{array}$ & Stat. & $\begin{array}{l}\text { Std. } \\
\text { Error }\end{array}$ \\
\hline $\begin{array}{l}\text { CUS1: } \\
\text { Changing price tags }\end{array}$ & 275 & 1 & 5 & 3.55 & 1.111 & -0.133 & 0.147 & -0.855 & 0.293 \\
\hline $\begin{array}{l}\text { CUS2: } \\
\text { A young adult uses child } \\
\text { or elderly Octopus Card }\end{array}$ & 278 & 1 & 5 & 4.19 & 0.892 & -1.238 & 0.146 & 1.611 & 0.291 \\
\hline $\begin{array}{l}\text { CUS3: } \\
\text { Use a lost stored value } \\
\text { card }\end{array}$ & 278 & 1 & 5 & 3.51 & 1.004 & -0.277 & 0.146 & -0.447 & 0.291 \\
\hline $\begin{array}{l}\text { CUS4: } \\
\text { Use an expired coupon }\end{array}$ & 278 & 1 & 5 & 3.40 & 0.981 & -0.399 & 0.146 & -0.255 & 0.291 \\
\hline $\begin{array}{l}\text { CUS5: } \\
\text { Get too much change } \\
\text { without saying anything }\end{array}$ & 278 & 1 & 5 & 3.37 & 0.929 & -0.077 & 0.146 & -0.235 & 0.291 \\
\hline $\begin{array}{l}\text { CUS6: } \\
\text { Record a musical album } \\
\text { instead of buying it }\end{array}$ & 278 & 1 & 5 & 3.19 & 0.926 & -0.204 & 0.146 & -0.141 & 0.291 \\
\hline $\begin{array}{l}\text { CUS7: } \\
\text { Buy a counterfeited } \\
\text { handbag or watch }\end{array}$ & 278 & 1 & 5 & 3.24 & 0.859 & 0.245 & 0.146 & -0.094 & 0.291 \\
\hline $\begin{array}{l}\text { CUS8: } \\
\text { Return an item after } \\
\text { finding it is now on sale }\end{array}$ & 278 & 1 & 5 & 3.23 & 0.930 & -0.211 & 0.146 & -0.300 & 0.291 \\
\hline $\begin{array}{l}\text { CUS9: } \\
\text { Use computer software } \\
\text { or games that you did } \\
\text { not buy }\end{array}$ & 278 & 1 & 5 & 3.02 & 0.957 & -0.068 & 0.146 & -0.175 & 0.291 \\
\hline Valid N (listwise) & 275 & & & & & & & & \\
\hline
\end{tabular}

The descriptive analysis of the measuring variables shows that consumers exhibited moderately high level of concern for ethical behaviour (mean value $=3.41$ ). And among the various unethical behaviours, respondents exhibited vast difference in their responses such as their attitudes towards using others' Octopus Card and that of illegally downloading computer software and games without even the intention of paying for them. The degree of materialism was moderate (mean value $=2.75)$.

\section{Factor Analysis for Reliability Testing}

Based on Table 6 below, the KMO measure of sample adequacy is 0.739 showing that the sampling adequacy is very good and meets the assumption of EFA. 
Table 6. KMO and Bartlett's Test for attitude towards Consumer Ethics

\begin{tabular}{|l|l|l|}
\hline Kaiser-Meyer-Olkin Measure of Sampling Adequacy. & 0.739 \\
\hline Bartlett's Test of Sphericity & Approx. Chi-Square & 653.437 \\
\cline { 2 - 3 } & Df & 66 \\
\cline { 2 - 3 } & Sig. & 0.000 \\
\hline
\end{tabular}

Table 6 also indicates that Bartlett's test of Sphericity to be $\chi^{2}=653.4$; $\mathrm{df}=66$; $\mathrm{p}$-value $=$ 0.0001 . Since $p$-value $<0.05$ (rules of thumb), implying that there is no identity matrix in the intercorrelation of variables. The ratio of sample size to the number of items (n/k) is $278 / 8 \approx$ 35 which is larger than 5 . Hence it is established that the data is appropriate for EFA.

Table 7. Rotated Component Matrix

\begin{tabular}{|l|l|l|}
\hline \multicolumn{2}{|l|}{ Component } \\
\hline & $\begin{array}{l}\text { Attitude toward } \\
\text { customer } \\
\text { (CUS) }\end{array}$ & $\begin{array}{l}\text { Attitude toward } \\
\text { possessing } \\
\text { materialistic } \\
\text { goods (MAT) }\end{array}$ \\
\hline CUS3: Use a lost stored value card & 0.703 & \\
\hline CUS7: Buy a counterfeited handbag or watch & 0.661 & \\
\hline CUS9: Use computer software or games that you did not buy & 0.657 & \\
\hline CUS4: Use an expired coupon & 0.632 & \\
\hline CUS8: Return an item after finding it is now on sale & 0.614 & \\
\hline CUS2: A young adult uses child or elderly Octopus Card & 0.610 & \\
\hline CUS6: Record a musical album instead of buying it & 0.582 & 0.755 \\
\hline CUS5: Get too much change without saying anything & 0.571 & 0.744 \\
\hline MAT6: Others judge me by the kinds of things I own. & & 0.586 \\
\hline MAT3: People judge others by what they own. & & 0.556 \\
\hline MAT4: I buy some things that I secretly hope will impress others. & & \\
\hline MAT7: People will like me more if I own the right things & & \\
\hline
\end{tabular}

Extraction Method: Principal Component Analysis.

Rotation Method: Varimax with Kaiser Normalization.

Rotation converged in 3 iterations.

The attitude toward customer ethics and attitude toward possessing materialistic goods was designed using 9 items and 7 items respectively. Table 7 shows factor loading pattern for component 1 and component 2 that seem to converge and discriminate as described in theory. It further shows that the 9 items for attitude toward customer ethics has been reduced to 8 items and highly loaded on component 1 or labelled here as attitude toward customer ethics (CUS). Meanwhile the 7 items of attitude toward possessing materialistic goods has been reduced to 4 items and loaded highly on component 2 or labelled as attitude toward possessing materialistic goods (MAT).

Referring to Table 8 below, Component 1 or CUS explains $26.83 \%$ of the explained variance in the 9 items tested. Component 2 or MAT explains $14.94 \%$ of explained variance. In total 
$41.8 \%$ of variance in the 16 items are explained, thus by reducing 5 items, $58.2 \%(100 \%$ $41.8 \%$ ) of information is lost. This indicates that slightly more than $50 \%$ of the data has been lost in this study.

Table 8. Total Variance Explained

\begin{tabular}{|l|l|l|l|l|l|l|}
\hline \multirow{2}{*}{ Component } & \multicolumn{2}{|l|}{ Initial Eigenvalues } & \multicolumn{2}{l|}{ Extraction Sums of Squared Loadings } \\
\cline { 2 - 7 } & Total & \% of Variance & Cumulative \% & Total & \% of Variance & Cumulative \% \\
\hline 1 & 3.219 & 26.826 & 26.826 & 3.219 & 26.826 & 26.826 \\
\hline 2 & 1.793 & 14.939 & 41.765 & 1.793 & 14.939 & 41.765 \\
\hline \multicolumn{2}{|l}{ Extraction Method: Principal Component Analysis. } \\
\hline
\end{tabular}

Referring to Table 9 below, the 8 items of CUS produced Cronbach's alpha of 0.80 . The 4 items of MAT produced Cronbach's alpha of 0.6. Both Cronbach's alpha values exceed the minimum requirement of 0.6 set by Nunnally (1978). Therefore, attitude toward customer ethics and attitude toward possessing materialistic goods are reliably measured.

Table 9. Cronbach's alpha

\begin{tabular}{|l|l|l|}
\hline Components & CUS & MAT \\
\hline Cronbach alpha & 0.80 & 0.60 \\
\hline Scale Mean & 27.2 & 10.9 \\
\hline Scale Standard Deviation & 4.7 & 2.3 \\
\hline No of items & 8 & 4 \\
\hline
\end{tabular}

After factor analysis, Cronbach's alpha was used to measure the consistency among the items in each variable of the questionnaire (Fenwick, Schellinck and Kendall, 1983). Variables with Cronbach's alpha value of 0.7 or higher are considered as having a good scale internal consistency and, therefore, are acceptable (Shin, Collier and Wilson, 2000). The variables had Cronbach's alpha value between 0.6 and 0.8 were, therefore, all considered acceptable.

\section{Hypothesis Testing}

After a detailed analysis of the data using exploratory factor analysis and reliability analysis, an acceptable level of appropriate validity and reliability of the data was ascertained. The data collected then could be used for testing the hypotheses. The five hypotheses were tested by using Pearson product moment correlation, independent samples t-test and multiple regression analysis statistical methods.

\section{Hypothesis H1: There is a positive relationship between materialism and unethical consumer behaviour.}

Table 10 below indicates, $r$ (correlation coefficient) $=0.057, p$-value $=0.173$, since $p$-value is $>0.05$, null hypothesis is not rejected, indicating no correlation between attitude towards possessing materialistic goods and attitude toward consumer unethical behaviour. 
Table 10. Correlation Table for Consumer Ethics and Materialism

\begin{tabular}{|l|l|l|l|}
\hline \multirow{3}{*}{ MAT } & Pearson Correlation & MAT & CUS \\
\cline { 2 - 4 } & Sig. (1-tailed) & 1 & 0.057 \\
\cline { 2 - 4 } & N & & 0.173 \\
\hline \multirow{2}{*}{ CUS } & Pearson Correlation & 0.057 & 278 \\
\cline { 2 - 5 } & Sig. (1-tailed) & 0.173 & 1 \\
\cline { 2 - 4 } & N & 278 & \\
\hline
\end{tabular}

Based on the above finding, $\mathrm{H} 1$ is not supported and there is no significant relationship between consumer ethics and materialism.

\section{Hypothesis H2: Females are more materialistic than males}

Independent samples t-test (one-tailed test) was used to test hypothesis $\mathrm{H} 2$ to reveal whether females are more materialistic than males. In order to enable the use of the analysis, the data need to satisfy the following two assumptions.

Table 11. Independent Samples T-Test

\begin{tabular}{|c|c|c|c|}
\hline & & \multicolumn{2}{|l|}{ MAT } \\
\hline & & $\mid \begin{array}{l}\text { Equal variances } \\
\text { assumed }\end{array}$ & $\begin{array}{l}\text { Equal variances not } \\
\text { assumed }\end{array}$ \\
\hline \multirow{2}{*}{$\begin{array}{l}\text { Levene's Test for Equality } \\
\text { of Variances }\end{array}$} & $\mathbf{F}$ & 5.543 & \\
\hline & Sig. & 0.019 & \\
\hline \multirow{7}{*}{$\begin{array}{l}\text { t-test for Equality of } \\
\text { Means }\end{array}$} & & 0.330 & 0.332 \\
\hline & df & 272 & 267.921 \\
\hline & Sig. (2-tailed) & 0.741 & 0.740 \\
\hline & Mean Difference & 0.09414 & 0.09414 \\
\hline & Std. Error Difference & 0.28497 & 0.28392 \\
\hline & 95\% Confidence Interval of Lower & -0.46688 & -0.46487 \\
\hline & \begin{tabular}{|l|l|} 
the Difference & Upper
\end{tabular} & 0.65516 & 0.65314 \\
\hline
\end{tabular}

Homogeneity of variance is determined base on Table 11.

$\mathrm{H}_{0}: \sigma_{\mathrm{M}}^{2}=\sigma_{\mathrm{F}}^{2}$ (shows equality of variances - homogeneity)

$H_{1}: \sigma_{M}^{2} \neq \sigma_{F}^{2}$ (shows inequality of variances - heterogeneity)

Levene's test shows:

$\mathrm{F}=5.54$, $\mathrm{p}$-value $=0.02$, at $5 \%$ level of significance, $\mathrm{H}_{0}$ is rejected, hence homogeneity does not exist in the difference between the gender. 


\section{Macrothink}

Thus, equal variance not assumed column in table 4.16 is used to test significance

$\mathrm{H}_{0}: \mu_{\mathrm{F}}=\mu_{\mathrm{M}}$

$\mathrm{H}_{1}: \mu_{\mathrm{F}}>\mu_{\mathrm{M}}$

$\mathrm{t}=0.33, \mathrm{df}=268, \mathrm{p}$-value $=0.74 / 2=0.37$, since $\mathrm{p}$-value $>0.05, \mathrm{H}_{0}$ is not rejected, indicating that there is no difference between male and female's attitude towards possessing materialistic goods.

Table 12. Group Statistics of Independent Samples T-test

\begin{tabular}{|l|l|l|l|l|l|}
\hline \multirow{2}{*}{ MAT } & Respondent's Gender & N & Mean & Std. Deviation & Std. Error Mean \\
\cline { 2 - 6 } & Male & 134 & 11.0299 & 2.14840 & 0.18559 \\
\cline { 2 - 6 } & Female & 140 & 10.9357 & 2.54233 & 0.21487 \\
\hline
\end{tabular}

Table 12 above for testing nature of relationship indicates the average MAT for both gender is around 11 while the standard deviation of female MAT is slightly larger than the male.

On average, male's attitude toward possessing materialistic goods is slightly higher than female's. Male's average is 11.0 with a standard deviation of 2.15. Female's average is 10.9 with a standard deviation of 2.54. The larger variance in Female's attitude toward possessing materialistic goods may be due to their preference for some goods but not for other goods.

Thus this shows that $\mathrm{H}_{2}$ : Females are more materialistic than Males is not supported.

\section{Hypothesis H3: Age positively moderates the relationship between Materialism and Consumer Ethics}

To analyse the moderating effect of age on the relationship between materialism and consumer ethics, multiple regression analysis was used.

An ANOVA was conducted in testing of significance of the model. 
Table 13. ANOVA Table for the Testing Moderating Effect of Age

\begin{tabular}{|c|c|c|c|c|c|c|}
\hline \multicolumn{7}{|c|}{ ANOVA } \\
\hline & del & Sum of Squares & df & Mean Square & $\mathbf{F}$ & Sig. \\
\hline \multirow{3}{*}{1} & Regression & 0.490 & 1 & 0.490 & 0.489 & $0.485 \mathrm{a}$ \\
\hline & Residual & 296.510 & 296 & 1.002 & & \\
\hline & Total & 297.000 & 297 & & & \\
\hline \multirow{3}{*}{2} & Regression & 25.180 & 2 & 12.590 & 13.664 & $0.000 \mathrm{~b}$ \\
\hline & Residual & 271.820 & 295 & 0.921 & & \\
\hline & Total & 297.000 & 297 & & & \\
\hline \multirow{3}{*}{3} & Regression & 30.416 & 3 & 10.139 & 11.181 & $0.000 \mathrm{c}$ \\
\hline & Residual & 266.584 & 294 & 0.907 & & \\
\hline & Total & 297.000 & 297 & & & \\
\hline
\end{tabular}
a. Predictors: (Constant), MAT
b. Predictors: (Constant), MAT, AGE
c. Predictors: (Constant), MAT, AGE, MATAGE
d. Dependent Variable: CUS

$\mathrm{H}_{0}$ : Model does not fit the data

$\mathrm{H}_{1}$ : Model fits the data

The above ANOVA in Table 13 shows model 3, with the moderating term of MATAGE added, is significant because $F=11.181$, degrees of freedom $(\mathrm{df})=3$, $\mathrm{p}$-value $=0.0001$, which indicates a decision rule that rejects $\mathrm{H}_{0}$ as $\mathrm{p}$-value $<0.05$. Thus the moderation effect model significantly fits the data.

Table 14. Coefficients Table for the Testing Moderating Effect of Age

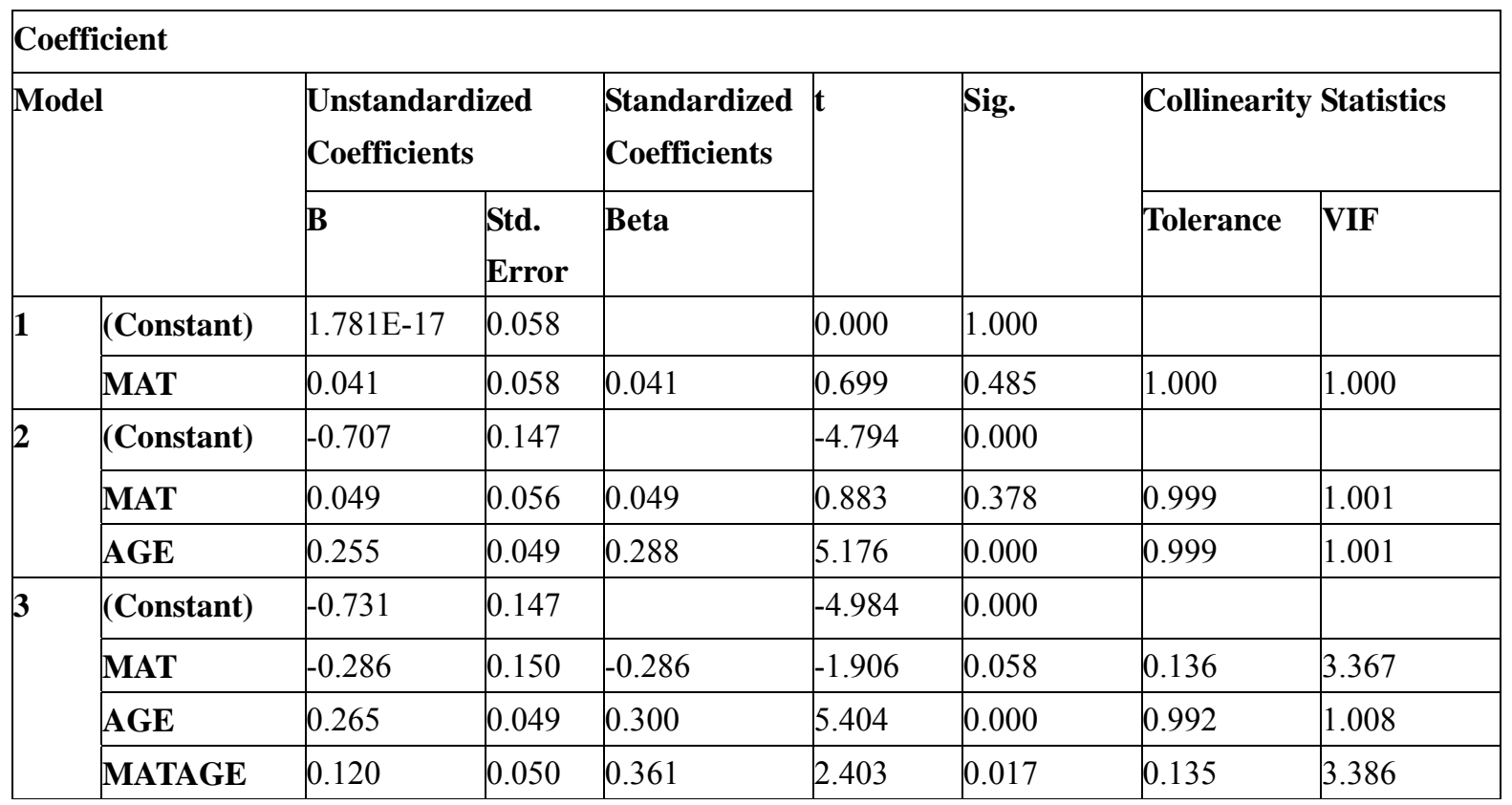

a. Dependent Variable: CUS 
Referring to Table 14 above, the standardized regression formula for the moderating effect of age on the relationship between consumer ethics and materialism is as follows:

$\mathrm{CUS}=-0.286 * \mathrm{MAT}+0.3 * \mathrm{AGE}+0.361 *$ MATAGE

i) Testing the influence of MAT on CUS

$\mathrm{H}_{0}: \beta 1=0$ (MAT does not influence CUS)

$\mathrm{H}_{1}: \beta 1 \neq 0$ (MAT influences CUS)

$\mathrm{t}=-1.906, \mathrm{p}$-value $=0.058$, since $\mathrm{p}$-value $>0.05, \mathrm{H}_{0}$ is not rejected, MAT is not a significant variable that influences CUS

ii) Testing influence of MATAGE on CUS

$\mathrm{H}_{0}: \beta 2=0$ (MATAGE does not influence CUS)

$\mathrm{H}_{1}: \beta 2 \neq 0$ (MATAGE influences CUS)

$\mathrm{t}=2.403, \mathrm{p}$-value $=0.017$, since $\mathrm{p}$-value $<0.05, \mathrm{H}_{0}$ is rejected, MATAGE is a significant variable that influences CUS.

Thus it can be concluded that age is a moderating variable.

The model summary in Table 15 for testing the strength of relationship indicates that, by adding the moderating term (MATAGE), the adjusted $\mathrm{R}^{2}$ increased from 0.079 to 0.093 and significant $(\mathrm{p}=0.017)$.

Table 15. Model Summary for the Testing Moderating Effect of Age

\begin{tabular}{|c|c|c|c|c|c|c|c|c|c|}
\hline \multicolumn{10}{|c|}{ Model Summary } \\
\hline \multirow[t]{3}{*}{ Model } & \multirow[t]{3}{*}{$\mathbf{R}$} & \multicolumn{8}{|c|}{ R Square Adjusted Std. Error of Change Statistics } \\
\hline & & & \multicolumn{2}{|c|}{ R Square the Estimate } & \multicolumn{2}{|c|}{ R $\quad$ Square F Change } & \multirow[t]{2}{*}{ df1 } & \multirow[t]{2}{*}{ df2 } & \multirow[t]{2}{*}{ Sig. F Change } \\
\hline & & & & & Change & & & & \\
\hline 1 & $0.041 \mathrm{a}$ & 0.002 & -0.002 & 1.00086142 & 0.002 & 0.489 & 1 & 296 & 0.485 \\
\hline 2 & $0.291 \mathrm{~b}$ & 0.085 & 0.079 & 0.95990827 & 0.083 & 26.796 & 1 & 295 & 0.000 \\
\hline 3 & $0.320 \mathrm{c}$ & 0.102 & 0.093 & 0.95223305 & 0.018 & 5.775 & 1 & 294 & 0.017 \\
\hline
\end{tabular}

a. Predictors: (Constant), MAT

b. Predictors: (Constant), MAT, AGE

c. Predictors: (Constant), MAT, AGE, MATAGE

In addition, referring to Table $15, \mathrm{VIF}=3.39$ which is smaller than 5 . This shows that the independent constructs are independent from each other and no multicollinearity exists between the independent variables. According to the above findings, H3 is supported.

\section{Hypothesis H4: Income positively moderates the relationship between Materialism and} Consumer Ethics

The ANOVA in Table 16 below for testing of significance shows that model 3, with the moderating term of MATINC added, is significant because $\mathrm{F}=2.842$, degrees of freedom (df) 
$=3$, p-value $=0.038$, indicates a decision rule that rejects the null hypothesis $\mathrm{H}_{0}$ as $\mathrm{p}$-value $<$ 0.05 . Thus the moderation effect model significantly fits the data.

Table 16. ANOVA Table for the Testing Moderating Effect of Income

\begin{tabular}{|l|l|l|l|l|l|l|}
\hline \multirow{1}{1}{} & Regression & 0.490 & 1 & 0.490 & 0.489 & $0.485 \mathrm{a}$ \\
\cline { 2 - 8 } & Residual & 296.510 & 296 & 1.002 & & \\
\cline { 2 - 8 } & Total & 297.000 & 297 & & & \\
\hline \multirow{2}{*}{$\mathbf{3}$} & Regression & 8.159 & 2 & 4.079 & 4.166 & $0.016 \mathrm{~b}$ \\
\cline { 2 - 8 } & Residual & 288.841 & 295 & 0.979 & & \\
\cline { 2 - 8 } & Total & 297.000 & 297 & & & \\
\hline & Regression & 8.370 & 3 & 2.790 & 2.842 & $0.038 \mathrm{c}$ \\
\cline { 2 - 8 } & Residual & 288.630 & 294 & 0.982 & & \\
\cline { 2 - 7 } & Total & 297.000 & 297 & & & \\
\hline
\end{tabular}
a. Predictors: (Constant), MAT
b. Predictors: (Constant), MAT, INCOME
c. Predictors: (Constant), MAT, INCOME, MATINC
d. Dependent Variable: CUS

Referring to Table 17 below, the standardized regression formula for the moderating effect of income on the relationship between consumer ethics and materialism is as follows:

CUS $=-0.038 *$ MAT $+0.162 *$ INCOM $+0.07 *$ MATINC

Table 17. Coefficients Table for the Testing Moderating Effect of Income

\begin{tabular}{|c|c|c|c|c|c|c|c|c|}
\hline \multicolumn{9}{|c|}{ Coefficients } \\
\hline \multirow{2}{*}{\multicolumn{2}{|c|}{ Model }} & \multicolumn{2}{|c|}{$\begin{array}{l}\text { Unstandardized } \\
\text { Coefficients }\end{array}$} & \multirow{2}{*}{\begin{tabular}{|l} 
Standardized \\
Coefficients
\end{tabular}} & \multirow{2}{*}{ t } & \multirow[t]{2}{*}{ Sig. } & \multicolumn{2}{|c|}{$\begin{array}{l}\text { Collinearity } \\
\text { Statistics }\end{array}$} \\
\hline & & B & \begin{tabular}{|l} 
Std. \\
Error
\end{tabular} & & & & \multirow[t]{2}{*}{ Tolerance } & VIF \\
\hline \multirow[t]{2}{*}{1} & (Constant) & $1.781 \mathrm{E}-17$ & 0.058 & & 0.000 & 1.000 & & \\
\hline & MAT & 0.041 & 0.058 & 0.041 & 0.699 & 0.485 & 1.000 & 1.000 \\
\hline \multirow[t]{3}{*}{2} & (Constant) & -0.340 & 0.134 & & -2.531 & 0.012 & & \\
\hline & MAT & 0.028 & 0.058 & 0.028 & 0.483 & 0.629 & 0.994 & 1.006 \\
\hline & INCOME & 0.107 & 0.038 & 0.161 & 2.799 & 0.005 & 0.994 & 1.006 \\
\hline \multirow[t]{4}{*}{3} & (Constant) & -0.345 & 0.135 & & -2.556 & 0.011 & & \\
\hline & MAT & -0.038 & 0.152 & -0.038 & -0.246 & 0.805 & 0.143 & 7.008 \\
\hline & INCOME & 0.108 & 0.038 & 0.162 & 2.813 & 0.005 & 0.992 & 1.009 \\
\hline & MATINC & 0.019 & 0.041 & 0.070 & 0.464 & 0.043 & 0.143 & 3.985 \\
\hline
\end{tabular}

a. Dependent Variable: CUS

i) Testing influence of MAT on CUS

$\mathrm{H}_{0}: \beta 1=0$ (MAT does not influence CUS) 
$\mathrm{H}_{1}: \beta 1 \neq 0$ (MAT influences CUS)

$\mathrm{t}=-0.246, \mathrm{p}$-value $=0.805$, since $\mathrm{p}$-value $>0.05, \mathrm{H}_{0}$ is not rejected, MAT is not a significant variable that influences CUS

ii) Testing influence of MATINC on CUS

$\mathrm{H}_{0}: \beta 2=0$ (MATINC does not influence CUS)

$\mathrm{H}_{1}: \beta 2 \neq 0$ (MATINC influences CUS)

$\mathrm{t}=0.464, \mathrm{p}$-value $=0.043$, since $\mathrm{p}$-value $<0.05, \mathrm{H}_{0}$ is rejected, MATINC is a significant variable that influences CUS.

Thus it can be concluded that income is a moderating variable.

The model summary in Table 18 for testing the strength of relationship indicates that, by adding the moderating term (MATINC), the adjusted $\mathrm{R}^{2}$ increased from 0.021 to 0.028 and significant $(\mathrm{p}=0.043)$.

Table 18. Model Summary for the Testing Moderating Effect of Income

\begin{tabular}{|c|c|c|c|c|c|c|c|c|}
\hline \multicolumn{9}{|c|}{ Model Summary } \\
\hline \multirow{2}{*}{ Model|F } & & \multirow{2}{*}{ R Square } & \multirow{2}{*}{ Adjusted R Square } & \multicolumn{5}{|c|}{ Std. Error of the Estimate Change Statistics } \\
\hline & & & & & R Square Change & F Chang & edf1 & df2 Sig. F Change \\
\hline 1 & $0.041 \mathrm{a}$ & 0.002 & -0.002 & 1.00086142 & 0.002 & 0.489 & 1 & 2960.485 \\
\hline 2 & $0.166 \mathrm{~b}$ & 0.027 & 0.021 & 0.98950666 & 0.026 & 7.832 & 1 & 2950.005 \\
\hline 3 & $0.168 \mathrm{c}$ & 0.028 & 0.028 & 0.99082557 & 0.001 & 0.215 & & 2940.043 \\
\hline
\end{tabular}

a. Predictors: (Constant), MAT

b. Predictors: (Constant), MAT, INCOME

c. Predictors: (Constant), MAT, AGE, MATINC

Referring to Table 18 above, VIF $=3.9$ which is $<5$. This shows that the independent constructs are independent from each other and there is no multicollinearity between the independent variables. Based on the above findings, $\mathrm{H} 4$ is supported.

\section{Hypothesis H5: Education positively moderates the relationship between Materialism and Consumer}

\section{Ethics}

The ANOVA in Table 19 below for testing of significance shows that model 3, with the moderating term of MATEDU added, is significant because $F=2.362$, degrees of freedom (df) $=3, p$-value $=0.068$, indicates a decision rule that accepts the null hypothesis $\mathrm{H}_{0}$ as $\mathrm{p}$-value $>$ 0.05 . Thus the moderation effect model insignificantly fits the data. 
Table 19. ANOVA Table for the Testing Moderating Effect of Education Level

\begin{tabular}{|c|c|c|c|c|c|c|}
\hline \multicolumn{7}{|c|}{ ANOVA } \\
\hline Model & & Sum of Squares & df & Mean Square & $\mathbf{F}$ & Sig. \\
\hline \multirow[t]{3}{*}{1} & Regression & 0.490 & 1 & .490 & 0.489 & $0.485 a$ \\
\hline & Residual & 296.510 & 296 & 1.002 & & \\
\hline & Total & 297.000 & 297 & & & \\
\hline \multirow[t]{3}{*}{2} & Regression & 5.589 & 2 & 2.794 & 2.829 & $0.061 \mathrm{~b}$ \\
\hline & Residual & 291.411 & 295 & 0.988 & & \\
\hline & Total & 297.000 & 297 & & & \\
\hline \multirow[t]{3}{*}{3} & Regression & 7.085 & 3 & 2.362 & 2.395 & $0.068 \mathrm{c}$ \\
\hline & Residual & 289.915 & 294 & 0.986 & & \\
\hline & Total & 297.000 & 297 & & & \\
\hline
\end{tabular}

a. Predictors: (Constant), MAT

b. Predictors: (Constant), MAT, Education level

c. Predictors: (Constant), MAT, Education level, MATEDU

d. Dependent Variable: CUS

Referring to Table 20 below, the standardized regression formula for the moderating effect of education level on the relationship between consumer ethics and materialism is as follows:

$\mathrm{CUS}=0.12 * \mathrm{MAT}+0.067 * \mathrm{EDU}+0.07 * \mathrm{MATEDU}$

Table 20. Coefficients Table for the Testing Moderating Effect of Education Level

\begin{tabular}{|c|c|c|c|c|c|c|c|c|}
\hline \multicolumn{9}{|c|}{ Coefficients } \\
\hline \multirow{3}{*}{\multicolumn{2}{|c|}{ Model }} & \multirow{2}{*}{\multicolumn{2}{|c|}{$\begin{array}{l}\text { Unstandardized } \\
\text { Coefficients }\end{array}$}} & \multirow{3}{*}{\begin{tabular}{|l|} 
Standardized Coefficients \\
Beta \\
\end{tabular}} & \multirow{4}{*}{$\mid \begin{array}{l}t \\
0.000\end{array}$} & & \multirow{2}{*}{\multicolumn{2}{|c|}{$\begin{array}{l}\text { Collinearity } \\
\text { Statistics }\end{array}$}} \\
\hline & & & & & & & & \\
\hline & & \multirow{2}{*}{\begin{tabular}{|l} 
B \\
$1.781 \mathrm{E}-17$
\end{tabular}} & \multirow{2}{*}{$\begin{array}{l}\text { Std. Error } \\
0.058\end{array}$} & & & & \multirow[t]{2}{*}{ Tolerance } & \multirow[t]{2}{*}{ VIF } \\
\hline $\mathbf{1}$ & (Constant) & & & & & \begin{tabular}{l|l} 
& Sig. \\
& \\
0 & 1.000
\end{tabular} & & \\
\hline & MAT & 0.041 & 0.058 & 0.041 & 0.699 & 0.485 & 1.000 & 1.000 \\
\hline \multirow[t]{3}{*}{2} & (Constant) & -0.263 & 0.129 & & -2.034 & 0.043 & & \\
\hline & MAT & 0.062 & 0.058 & 0.062 & 1.054 & 0.293 & 0.975 & 1.026 \\
\hline & Education level & 0.151 & 0.066 & 0.133 & 2.272 & 0.024 & 0.975 & 1.026 \\
\hline \multirow[t]{4}{*}{3} & (Constant) & -0.265 & 0.129 & & -2.050 & 0.041 & & \\
\hline & MAT & -0.068 & 0.120 & -0.068 & -0.566 & 0.572 & 0.229 & 4.363 \\
\hline & Education level & 0.158 & 0.067 & 0.140 & 2.382 & 0.018 & 0.966 & 1.035 \\
\hline & MATEDU & 0.087 & 0.070 & 0.149 & 1.232 & 0.022 & 0.227 & 4.404 \\
\hline
\end{tabular}

a. Dependent Variable: CUS

i) Testing influence of MAT on CUS

$\mathrm{H}_{0}: \beta 1=0$ (MAT does not influence CUS)

$\mathrm{H}_{1}: \beta 1 \neq 0$ (MAT influences CUS) 
$\mathrm{t}=-0.566, \mathrm{p}$-value $=0.572$, since $\mathrm{p}$-value $>0.05, \mathrm{H}_{0}$ is not rejected, MAT is not a significant variable that influences CUS

ii) Testing influence of MATEDU on CUS

$\mathrm{H}_{0}: \beta 2=0$ (MATEDU does not influence CUS)

$\mathrm{H}_{1}: \beta 2 \neq 0$ (MATEDU influences CUS)

$\mathrm{t}=1.232, \mathrm{p}$-value $=0.022$, since $\mathrm{p}$-value $<0.05, \mathrm{H}_{0}$ is rejected, MATEDU is a significant variable that influences CUS.

Thus it can be concluded that education is a moderating variable.

The model summary in Table 21 below for testing strength of relationship indicates that, by adding the moderating term (MATEDU), the adjusted $\mathrm{R}^{2}$ increased from 0.012 to 0.014 and significant $(\mathrm{p}=0.022)$.

Table 21. Model Summary for the Testing Moderating Effect of Education Level

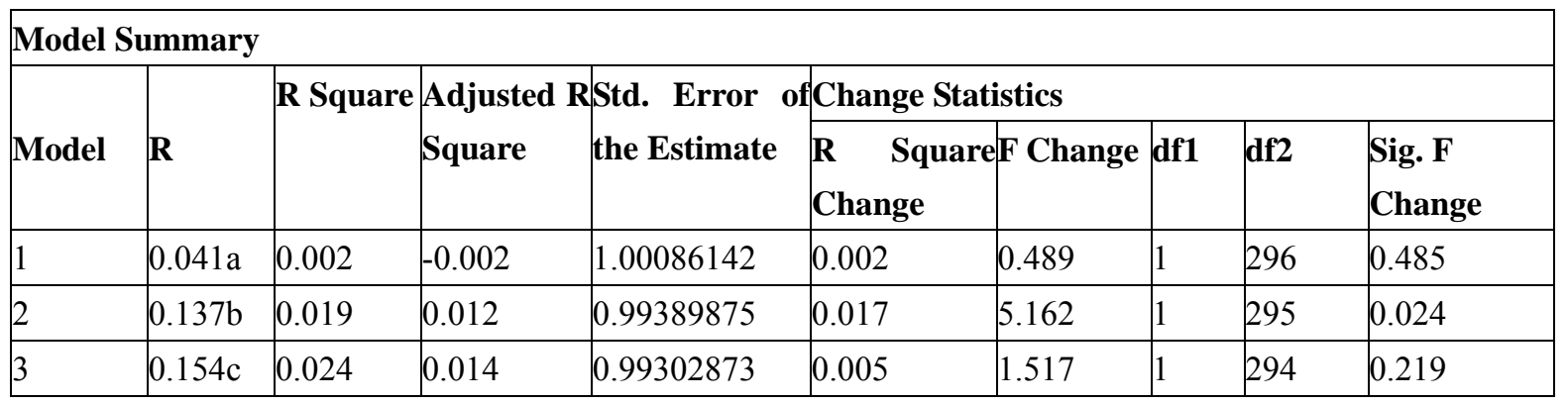

a. Predictors: (Constant), MAT

b. Predictors: (Constant), MAT, Education level

c. Predictors: (Constant), MAT, Education level, MATEDU

Referring to Table 21, VIF $=4.404$ which is $<5$. This shows that the independent constructs are independent from each other there is no multicollinearity between the independent variables. Based on the above findings, H5 is supported.

\section{Discussion}

Awareness of the importance of business ethics was raised as a result of the Enron scandal and the financial tsunamis of 1997 and 2008. However, although extensive research has been conducted on business ethics (Hunt and Vitell, 1993; Ferrel et al., 1989; Hunt and Vitell, 1986; Ferrel and Gresham, 1985), there is a lack of research on consumer ethics. Given that the unethical behaviour of consumers is causing financial harm to businesses and Governments (Bernstein, 1985), such research would be beneficial to society as a whole. With a better understanding of consumers' behaviour, policies and practices can be developed to effectively curtail malpractice and economic loss.

This study aims to investigate the correlational relationship between the phenomenon of materialism and consumers' unethical behaviour. The research also explored the moderating 
effects of age, income and education on such relationship, which had hitherto not been examined. This empirical research was conducted in the context of adult students from education institutes in Hong Kong. It was anticipated that a better understanding of consumers' attitude towards materialism and consumer ethics would be beneficial to the community at large.

\section{Major Contributions}

This study makes several contributions to the body of knowledge relating to the constructs of materialism and consumer ethics.

Firstly, although a considerable number of studies have examined the issues of consumer ethics and materialism (Muncy and Eastman, 1998; Muncy and Vitell, 1992; Richins and Dawson, 1992; Belk, 1985; Ward and Wackman, 1971), this research contributes to the knowledge of materialism and consumer ethics by examining the degree of materialism and consumer ethics of adult students in Hong Kong with a unique cultural setting itself. There was no recent research studying materialism in Hong Kong; similar research on ethical beliefs of consumers in Hong Kong was conducted more than ten years ago (Chan et al., 1998).

Results of the current research revealed that the ethical concern and materialism of consumers in Hong Kong is moderate. The study examined attitudes towards material possession and attitudes towards consumers' unethical behaviors. It produced an empirically verified fine-grained model to provide insights for both Hong Kong businesses and government on how consumers in Hong Kong perceived materialism and their own unethical behaviours.

Secondly, this research, to the researcher's knowledge, is the first empirical study to validate the relationship between materialism and consumer ethics of adult students in Hong Kong. The value of this research was that, given the large economic loss caused by unethical consumer behaviors, it is beneficial to identify key factors correlated with consumer ethics and directions of future research.

Results of this research indicated that education was an effective means in developing proper attitude towards material possession and ethical attitudes in young consumers. This research hoped to bring forth the phenomenon and raise people's awareness to understand more on materialism and consumer ethics

Thirdly, this research contributes to consumer ethics theory by providing evidence of respondents' attitudes towards four ethical dimensions. In general, the respondents showed moderate degree of concerns towards consumers' unethical behaviors. Among the four ethical dimensions, they showed more ethical concern over active, illegal behaviors than questionable behaviors. Results of the research indicated similar patterns with prior studies; consumers' attitudes towards four ethical dimensions did not differ much across all countries and further confirmed the applicability of the model of Muncy and Vitell (1992) in both east and west. Moreover, the results related to Octopus Card revealed that social norms and situational contexts played an important role in affecting consumers' attitudes towards 
behaviors with ethical concerns, which might be due to the culture of Hong Kong

Fourthly, this research contributes to the measures of materialistic attitudes (MMA) by providing evidence that respondents agreed with the three components of materialism including acquisition centrality, acquisition as the pursuit of happiness, and possession-defined success. It generalized the applicability of the measures to be used in Hong Kong context.

Fifthly, this research also contributes by adding a new perspective to the measure of materialistic attitudes (MMA). The findings indicate that respondents were more reserved in agreeing with materialistic attitudes when the statements were related to their own material possessions, rather than the material possessions of others. This resonates with findings from previous studies which indicated that consumers have a double-standard vis-a-vis their own behaviour and the behaviour of others (Chan, et al., 1998; Vitell et al., 1991; DePaulo, 1987). It indicates that neutralization technique applies to materialism as well as consumers' attitudes to unethical behaviour. Respondents also tended to agree that it is better to possess the right things rather than simply expensive things showing people in Hong Kong would not chase blindly after the luxury goods.

Last but not least, this research is not identical to any other research because Hong Kong has a unique culture which combines that of the East and the West. Moreover, Hong Kong is also one of the most developed Asian cities. These factors put Hong Kong in a different position from that of other Asian and Western countries.

\section{Limitations and Future Research}

Despite the study's success in revealing the constructs of materialism and consumers' ethics, the research itself had limitations that need to be identified and explained. Firstly, the data regarding materialism and consumers' ethics were collected by a self-reported questionnaire survey, meaning that the research relied on a single source of data collection. This might raise the question of common method variance. A second limitation of this study involved its inability to predict causal relationships because the data were cross-sectional rather than longitudinal. The findings can only show the correlation between the independent and dependent variables, but no conclusions can be drawn on whether the relationships are causal. Thirdly, this research applied a quantitative methodology to study materialism as a positive and significant correlational factor on consumers' ethics. Although it is recognized that there might be other contributing factors, this research only studied the effect of materialism as antecedent to consumers' unethical behaviour. Lastly, since the survey sample was restricted to adult students in Hong Kong and sampling method used is convenience sampling, there is a limitation to the generalization of the results to the populations in Hong Kong and other countries.

Based on the findings of the study, several recommendations are made for future research. Firstly, as this study collected data on a cross-sectional basis only, a longitudinal research aimed at investigating the effects over time of a variety of interventions, using multi-method measurements, could further the knowledge of causality of relationships and help determine 
what strategies could enhance consumers' ethical behaviour over time. Secondly, as this research was limited to Hong Kong's adult students, it is not clear if the factors investigated in this study apply equally to consumers at large. Future research is needed to examine this. Thirdly, the study's findings reveal that the relationship between materialism and consumer ethics is insignificant. However, the study is restricted to the education sector that may have its own spectrum of beliefs and values. Therefore, further research is needed to explore these relationships more extensively. Fourthly, the study examined the moderating impact of the demographic factors of age, income and education on the relationship. As there were no similar studies before, further and more extensive research is necessary. Lastly, only two constructs were examined in this study for the purpose of understanding the correlational factors associating materialism with consumer ethics. Further studies are recommended to consider other constructs which might also have an impact on consumer ethics.

\section{Conclusion}

The research findings conclude that there was a weak and insignificant relationship between consumers' perception towards materialistic possession and consumers' unethical behaviour in Hong Kong. The overall findings are in line with the study of Vitell et al. (2001).

Among the four ethical dimensions: active, passive, legal and questionable behaviours; results of this research indicate similar patterns with prior studies. Consumers' attitudes towards the four ethical dimensions did not differ much across all countries; there were more ethical concern over active, illegal behaviours than questionable behaviours.

The results of this research also indicate that the moderating effect of demographic factors of age, income and education impact the relationship between materialism and consumer ethics with medium or marginal strength. Moreover, the results related to Octopus Card reveal that social norms and situational contexts played an important role in affecting consumers' attitudes towards behaviours with ethical concerns, which might be due to the culture of Hong Kong.

Last but not least, this research reveal a new perspective which indicate that respondents were more reserved in agreeing with materialistic attitudes when the statements were related to their own material possessions, rather than the material possessions of others.

\section{References}

Achenreiner, G. (1997). Materialistic values and suscetibility to influence in children. Advances in Consumer Research, 24, 82-88.

Ajzen, I. (1991). The theory of planned behaviour. Organizational Behaviour and Human Decision Processes, 50, 179-211. http://dx.doi.org/10.1016/0749-5978(91)90020-T

Al-Khatib, J., Vitell, S. J., \& Rawwas, M. Y. A. (1996). Consumer Ethics: A Cross-Cultural Investigation, European Journal of Marketing, 31 (11-12), 750-767.

Ang, S. H., Cheng, P. S., Lim E. A. C., \& Tambyah S. K. (2001). Spot the Difference: Consumer Responses Towards Counterfeits, Journal of Consumer Marketing, 18(3), 219-235. 
http://dx.doi.org/10.1108/07363760110392967

Baron, R. M., \& Kenny, D. A. (1986). The moderator-mediator variable distinction in social psychological research: conceptual, strategic, and statistical considerations, Journal of $\begin{array}{llll}\text { Personality and Social } \quad \text { Psychology, } & \text { 51(6), }\end{array}$ http://dx.doi.org/10.1037/0022-3514.51.6.1173

Barrett, A. (1992). Crime Waves Spread very Democratically In Czechoslovakia; Even Toilet Paper Is Locked Away As New Breed of Thief Hails Western Materialism, The Wall Street Journal, B7B.

Baumhart, R. (1961). How ethical are business men?, Harvard Business Review, 38, 6-31.

Belk, R. W. (1985). Materialism: traits aspects of living in a material world, Journal of Consumer Research, 12(3), 265-280. http://dx.doi.org/10.1086/208515

Belk, R. W. (1988). Third World Consumer Culture, Research in Marketing, 4, 102-127.

Bernstein, P. (1985). Cheating - the new national pasttime? Business, 24-33.

Brenner, S. N., \& Molander, E. A. (1977). Is the Ethics of Business Executives changing? Harvard Business Review, 55, 57-71.

Bryman, A. (2004). Social Research Methods, Oxford: Oxford University.

Cavana, R., Delahaye, B., \& Sekaran, U. (2001). Applied Business Research: Qualitative and Quantitative Methods, John Wiley and Sons, Australia.

Chan, A., Wong, S., \& Leung, P. (1998). Ethical Beliefs of Chinese Consumers in Hong Kong, Journal of Business Ethics, 17(11), 1163-1170. http://dx.doi.org/10.1023/A:1005760729697

Chatzidakis, A., \& Mitussis, D. (2007). Computer ethics and consumer ethics: The impact of the internet on consumers' ethical decision-making process, Journal of Consumer Behaviour, 6(5), 305-320. http://dx.doi.org/10.1002/cb.223

Clarke, I., \& Micken, K. S. (2002). An exploratory cross-cultural analysis of values of materialism, Journal of International Consumer Marketing, 14(4), 65-86. http://dx.doi.org/10.1300/J046v14n04_05

Chung, W (1994). Rise of the Pirate Bloodsuckers, South China Morning Post, 15 March, p.17.

DePaulo, P. J. (1987). Ethical Perceptions of Deceptive Bargaining Tactics Used by Salespersons and Customers: A Double Standard, in Joel G. Sagert (ed.). Proceedings of the Division of Consumer Psychology. American Psychological Association, Washington, DC.

Eastman, J., Fredenberger, B., Campbell, D., \& Calvert, S. (1997). The relationship between status consumption and materialism: cross-cultural comparison of Chinese, Mexican, and American students, Journal of Marketing Theory and practices, 5(1), 52-65.

Fenwick, I., Schedllinck, D. A., \& Kendall, K. W. (1983). Assessing the Reliability of 
Psychographic Analyses, Marketing

Science, $\quad 2(1)$, $57-73$. http://dx.doi.org/10.1287/mksc.2.1.57

Ferrell, O. C., Gresham, L. G., \& Fraedrich J. (1989). A synthesis of ethical decision model for Marketing. Journal of Macromarketing, 11 (Fall), 55-64. http://dx.doi.org/10.1177/027614678900900207

Ferrell, O. C., \& Gresham, L. G. (1985). A Contingency Framework for Understanding Ethical Decision Making in marketing, Journal of Marketing, 49(3), 87-96. http://dx.doi.org/10.2307/1251618

Freestone, O., \& Mitchell, V. (2004) Generation Y Attitudes Towards E-ethics and Internet-related Misbehaviours. Journal of Business Ethics 54(2), 121-128. http://dx.doi.org/10.1007/s10551-004-1571-0

Fukukawa, K. (2002). Developing a framework for ethically questionable behaviour in consumption. Journal of Business Ethics, 15, 23-28

Garland, B., Kim, P., Lancster, W., \& Ponsford, B. (2006). Business and Marketing Student Attitudes Towards Learning Objectives Achieved in Classes and Extracurricular Activities, Proceedings of the Marketing Management Association, 87-93.

Geis, F.L., \& Moon, T. H. (1981). Machiavellianism and Deception, Journal of Personality and Social Psychology, 41(4), 766-775. http://dx.doi.org/10.1037/0022-3514.41.4.766

Ger, G., \& Belk, R.W. (1996). Cross-cultural differences in materialism, Journal of Econic Psychology, 17(1), 55-77. http://dx.doi.org/10.1016/0167-4870(95)00035-6

Goldberg, M. E., Gorn, G. J., Peracchio, L.A., \& Banossy, G. (2003). A scale to measure children's materialism. Journal of Consumer Psychology, 13, 283-288.

Grove, S. J., Vitell, S. J., \& Strutton, D (1989). Non-Normative Consumer Behaviour and the Techniques of Neutralisation, in Proceedings of the 1989 AMA Winter Educators' Conference, American Marketing Association.

Hair, J. F., Anderson, R.E., Tatham, R.L., \& Black, W.C. (1995). Multivariate data analysis with readings, 4th ed., Prentice Hall, Englewood Cliffs, New Jersey.

Hair, J. F., Black, B., Babin, B., Anderson, R. E., \& Tatham, R. L. (2006). Multivariate data analysis, 6th ed., Upper Saddle River, N.J. Prentice Hall.

Hofstede, G. (2002). Dimensions Do Not Exist: A reply to Brendan McSweeney. Human Relations (Sage Publications), 55(11).

Hunt, S. D., \& Vitell, S. J. (1992). The general theory of marketing ethics: A Retrospective and Revision: A retrospective and revision, in N. Craig Smith and John A. Quelch (eds), Ethics in Marketing, Journal of MacroMarketing, 8(Spring), 5-12.

Hunt, S. D., \&Vitell, S. J. (1986). A General Theory of Marketing Ethics, Journal of Macromarketing, 6(1), 5-16. http://dx.doi.org/10.1177/027614678600600103 
Kasser, T. (2002). The high price of materialism, Cambridge, MA : MIT Press.

Kasser, T., \& Ryan, R. M. (2001). Be careful what you wish for: optimal functioning and the relative attainment of intrinsic and extrinsic goals, in P. Schmuck and K. M. Sheldon (eds.), life goals and well-being: Towards a positive psychology of human striving, 116-131, Ashland, $\mathrm{OH}$ : Hogrefe and Huber.

Kwong, K. K., Yau, H. M., Lee, S. Y., Sin, Y. M., \& Tse, C. B. (2003). The Effects of Attitudinal and Demographic Factors on Intention to Buy Pirated CDs: The Case of Chinese Consumers. Journal of Business Ethics, 47(3), 223-235. http://dx.doi.org/10.1023/A:1026269003472

Lascu, D. N. (1993). Assessing Consumer Ethics: Scale Development Considerations for International Marketing', in Rajan Varadarajan and Bernard Jaworski (edsl), Proceedings of the American Marketing Association Winter Educators' Conference, 57-61.

Lu, L. C., \& Lu, C. J. (2009). Moral Philosophy, Materialism, and Consumer Ethics: An Exploratory Study in Indonesia, Journal of Business Ethics, 94(2), 193-210. http://dx.doi.org/10.1007/s10551-009-0256-0

Lundstrom, W. J., \& White, D. S. (1999). Intergenerational and cultural differences in materialism: an empirical investigation of consumers in France and the USA, Journal of Euro Marketing, 7, 47-65. http://dx.doi.org/10.1300/J037v07n02_04

Machiavelli, Niccolò. (1531). The Discourses. Translated by Leslie J. Walker, S.J, revisions by Brian Richardson (2003). London: Penguin Books. ISBN 0-140-44428-9

McDonald, G. M., \& Zepp, R. A. (1988), Ethical Perceptions of Hong Kong Chinese Business Managers, Journal of Business Ethics, 7(11), 835-845. http://dx.doi.org/10.1007/BF00383046

Ming Pao Daily. (2009). Index of Happiness, 20 October 2009, 13

Mochis, G., \& Churchill, G. (1978). Consumer socialization: a theoretical and empirical analysis, Journal of Marketing Research, 15(4), 599-609. http://dx.doi.org/10.2307/3150629

Morse, J. M., Barrett, M., Mayan, M, Olson, K., \& Spiers, J. (2002). Verification strategies for establishing reliability and validity in qualitative research, International Journal of Qualitative Methods, 1(2), 1-19.

Muncy, J. A., \& Eastman, J. K. (1998), Materialism and Consumer Ethics: An Exploratory Study, Journal of Business Ethics, 17(2), 137-145. http://dx.doi.org/10.1023/A:1005723832576

Muncy, J. A., \& Vitell S. J. (1992), Consumer Ethics: An investigation of the Ethical Beliefs of the Final Consumer, Journal of Business Research, 24(4), 297-311. http://dx.doi.org/10.1016/0148-2963(92)90036-B

Ng, S.L. (2005). Subjective Residential Environment and its Implications for Quality of Life Among University Students in Hong Kong, Social Indicators Research, 71(1-3), 467-489. 
http://dx.doi.org/10.1007/s11205-004-8032-0

Nunnally, J. C. (1978). Psychometric theory (2nd ed.). New York: McGraw-Hill.

O'Fallon, M. J., \& Butterfield, K. D. (2005). A review of empirical ethical decision-making literature: 1996-2003, Journal of Business Ethics, 59, 375-413. http://dx.doi.org/10.1007/s10551-005-2929-7

Rallapalli, K. C., Vitell, S. J., Wiebe, F. A., \& Barnes, J. H. (1994). Consumer Ethical Beliefs and Personality Traits: An Exploratory Analysis, Journal of Business Ethics, 13(7), 487-495. http://dx.doi.org/10.1007/BF00881294

Rawwas, M. Y. A., Patzer, G., \& Klassen, M. (1995). Consumer Ethics in Cross Cultural Settings, European Journal of Marketing, 29(7), 62-78. http://dx.doi.org/10.1108/03090569510095017

Rawwas, M. Y. A., Patzer, G. J., \& Vitell, S. J. (1998), A Cross-Cultural Investigation of the Ethical Values of Consumers: The Potential Effect $\mathrm{f}$ Civil War and Civil Disruption, Journal of Business Ethics, 17(4), 435-448. http://dx.doi.org/10.1023/A:1005788421138

Rawwas, M. Y. A., Strutton, D., \& Johnson, L. W. (1996), An Exploratory Investigation of the Ethical Values of American and Australian Consumers, Journal of Direct Marketing, 10(Autumn), 52-63. http://dx.doi.org/10.1002/(SICI)1522-7138(199623)10:4<52::AID-DIR5>3.0.CO;2-W

Rawwas, M. Y. A., Vitell, S. J., \& Al-Khabib J. (1994). Consumer ethics: The possible effects of Terrorism and Civil Unrest on the Ethical Values of Consumers, Journal of Business Ethics, 3(March), 223-231. http://dx.doi.org/10.1007/BF02074821

Reitman, V. (1996). Japan's new growth industry: schoolgirl prostitution - prevention efforts are blocked by tax laws - and mother's groups. Wall Street Journal (Eastern Edition). 2(October), A14.

Richins, M. L., \& Dawson, S. (1992). A Consumer Values Orientation for Materialism and its Measurement: Scale Development and Validation, Journal of Consumer Research, 19(3), 303-316. http://dx.doi.org/10.1086/209304

Rudmin, F., \& Richins, M. (1992). Meaning, Measure and Morality of Materialism, Association for Consumer Research, Provo, UT.

Schaefer, A. D., Hermans, C. M., \& Parker, R. S. (2004). A cross-cultural exploration of materialism in adolescents, International Journal of Consumer Studies, 28(4), 399-411. http://dx.doi.org/10.1111/j.1470-6431.2004.00395.x

Schubert, J. T. (1979). 'Consumer Abuse: Some Recommendations for change', in N. M. Ackerman (eds.), Proceedings, 25th Annual Conference of the American Council on Consumer Interests, pp. 146-149

Shin, H., Collier, D. A., \& Wilson, D. D. (2000). Supply Management Orientation and Supplier/Buyer Performance, Journal of Operations Management, 18(3), 317-333. 
http://dx.doi.org/10.1016/S0272-6963(99)00031-5

Schubert, J. T. (1979). 'Consumer Abuse: Some Recommendations for change', in N. M. Ackerman (eds.), Proceedings, 25th Annual Conference of the American Council on Consumer Interests, pp. 146-149

Singhapakdi, A., \& Rawwas, M. Y. A. (1998). Do Consumers' Ethical Beliefs Vary With Age? A substantiation of Kohlberg's Typology in Marketing. Journal of Marketing Theory and Practice Spring 1998; (6,2; ABI/INFORM Global).

Singhapakdi, A., \& Vitell, S. J. (1990). Marketing Ethics: Factors Influencing Perceptions of Ethical Problems and Alternatives, Journal of Macromarketing, 10(1), 4-18. http://dx.doi.org/10.1177/027614679001000102

Smith, M.L., \& Glass, G.V. (1987). Research and evaluation in education and the social sciences, Allyn and Bacon, USA.

Stampfl, R. W. (1979). Multi-Disciplinary Foundations for a Consumer Code of Ethics, in Proceedings, 25th Annual Conference of the American Council on Consumer Interests. N. M. Ackerman, ed., American Council on Consumer Interests, 12-20

Swaidan, Z. (1999). Consumer Ethics and Acculturation: The case of the Muslim Minority in the U.S., University of Mississippi.

Sylvia-Bobiak, S., \& Caldwell, L.L. (2006). Factors Related to Physically Active Leisure among College Students, Leisure Sciences, 28(1), 73-89. http://dx.doi.org/10.1080/01490400500332728

Thong, J. Y. L., \& Yap, C. S. (1998). Testing an ethical decision-making theory: the case of shoplifting, Journal of Management Information Systems, 15, 213-237.

Trevino, L. (1986). Ethical Decision Making in Organizations: A Person-Situation Interactionist Model, Academy of Management Review, 11(3), 601-617.

Turnbull, R. (2001). Fraud and the New Technology - A Hong Kong Perspective, Paper presented at the 17th Law Asia Biennial Conference, Christchurch, New Zealand.

Violet, D., Garland, T. N., \& Pendleton, B.F. (1986), High School Students' Marital Lifestyle Preferences: A Test of Reference Group Theory, Human Relations, 39(11), 1053-1067. http://dx.doi.org/10.1177/001872678603901107

Vitell, S. J. (2003). Consumer Ethics Research: Review, Synthesis and Suggestions for the Future, Journal of Business $\quad$ Ethics, 43(1-2), 33-47. http://dx.doi.org/10.1023/A:1022907014295

Vitell, S. J., \& Festervand, T. (1987). Business Ethics: Conflicts, Practices and Beliefs of Industrial Executive, Journal of Business Ethics, 6(2), 111-122. http://dx.doi.org/10.1007/BF00382024

Vitell, S. J., \& Muncy, J. (1992). Consumer Ethics: An Empirical Investigation of Factors 


\section{IIMacrothink}

Journal of Management Research

ISSN 1941-899X 2012, Vol. 4, No. 2

Influencing Ethical Judgments of the Final Consumer, Journal of Business Ethics, 11(8), 585-597. http://dx.doi.org/10.1007/BF00872270

Vitell, S. J., \& Muncy, J. (2005). The Muncy-Vitell Consumer Ethics Scale: a Modification and Application, Journal of Business Ethics, 62 (3), 267-275. http://dx.doi.org/10.1007/s10551-005-7058-9

Vitell, S. J., Lumpkin, J. R., \& Rawwas, M. Y. A. (1991). Consumer Ethics: An investigation of the Ethical Beliefs of Elderly Consumers, Journal of Business Ethics, 10(5), 365-375. http://dx.doi.org/10.1007/BF00383238

Vitell, S. J., Singhapakdi, A., \& Thomas, J. (2001). Consumer Ethics: An Application and Empirical Testing of the Hunt-Vitell Theory of Ethics, Journal of Consumer Marketing, 18(2), 153-178. http://dx.doi.org/10.1108/07363760110386018

Wackman, D. B., Reale, G., \& Ward, S. (1972). Racial differences in responses to advertising among adolescents, Effects of Advertising, 4, 543-553.

Ward, S., \& Wackman, D. (1971). Family and media influences on adolescent consumer learning. American Behvioral Scientist, $14(3), \quad$ 415-427. http://dx.doi.org/10.1177/000276427101400315 